\title{
Ritual consumption of psychoactive fungi and plants in ancestral Costa Rica*
}

\author{
JOSÉ M. RODRÍGUEZ ARCE ${ }^{1,2 * *}$ and MARCO A. ARCE CERDAS ${ }^{3 * *}$ \\ ${ }^{1}$ School of Anthropology, University of Costa Rica, San José, Costa Rica \\ ${ }^{2}$ Research Department, Costa Rican Association for Drug Study and Intervention (ACEID), San José, Costa Rica \\ ${ }^{3}$ Collections Management, Museums of the Central Bank of Costa Rica, San José, Costa Rica
}

(Received: November 21, 2018; accepted: March 5, 2019)

\begin{abstract}
Not much is known from an ethnohistorical perspective about the use of psychoactive substances in southern Central America; it is mainly through the archeological record that their presence in the past has been inferred. This article reviews evidence for the use of mind-altering plants and mushrooms in the societies that inhabited the current Costa Rican territory during pre-Columbian times, and explores the cultural significance of this activity. Historical, ethnographic, archeological, and paleobotanical information was examined and integrated with the data obtained from the analysis of 46 artifacts with a presumed linkage to psychoactive drug use that were selected from an exhaustive search in the collections of the Museums of the Central Bank of Costa Rica and the National Museum of Costa Rica. Preliminary results suggest the consumption of tobacco (Nicotiana spp. L.), morning glory (Ipomoea spp. L.), cohoba [Anadenanthera peregrina (L.) Speg.], psychedelic fungi [Amanita muscaria (L.) Lam. and Psilocybe (Fr.) P. Kumm. species], as well as various alcoholic and invigorating beverages was present in ancient times. This use was likely connected to shamanistic healing practices, social-ceremonial events, and the ritual activities of people who held positions of religious and political importance within society.
\end{abstract}

Keywords: psychoactive substances, Costa Rica, tobacco, cohoba, psychedelic mushrooms, Ipomoea

\section{INTRODUCTION}

Psychoactive fungi and plants have been incorporated time and again into the medicine, ritual life, and leisure of diverse human populations throughout the world (Guerra-Doce, 2015; Guzmán, 2013; Kennedy, 2014; Quirce, Badilla, Badilla, Martínez, \& Rodríguez, 2010; Rätsch, 2005; Schultes, Hofmann, \& Rätsch, 2001). There is a wealth of information in the ethnographic literature about the historical and cultural context of the use of these inebriants (e.g., mushrooms, cactus, herbs, and vines, as well as preparations of them such as snuffs and concoctions) in the indigenous societies of Mesoamerica and South America (Benítez, 2006; Bennett, 1992; Dobkin de Ríos, 1984; Furst, 1990; Harner, 1973; Schultes et al., 2001). However, for southern Central America, and specifically for Costa Rica, there is little documentary evidence of the use of psychoactive substances; it is mainly through the archeological record that the occurrence and relevance of such behavioral pattern in the past has been indirectly inferred (Jones, 1991; Stone, 2011).

Southern Central America was populated by small agrarian societies that gave shape to tribal and, in their later periods, chiefdom sociopolitical systems (Geurds, 2018; Murillo \& Martín, 2017). In contrast to the cultural evolutionary landscape in Mesoamerica and South America, these societies managed to uphold a relatively simple and not very hierarchical form of organization during many centuries, avoiding the process of developing into more unstable and costly social forms such as states and empires (Arias \& Murillo, 2014; Drennan, 1995; Joyce, 2013a). From a certain period onward, pre-Columbian Costa Rican peoples thus lived in agricultural villages of varying sizes that had their local (tribal) leader; in addition, there were higher ranking regional leaders who acted as military or religious chiefs and guides, or economic regulators - but there were no supreme rulers nor marked inequalities in wealth (Murillo \& Martín, 2017).

In this article, we present the results of an ongoing investigation on the presence and cultural significance of the ingestion of psychoactive plants and mushrooms in the societies that inhabited the current Costa Rican territory throughout Periods IV-VI (ca. 1000 BCE-1550 CE). The main objectives have been the following: first, to systematically document the use of such inebriants through different

\footnotetext{
* Some of the evidence and ideas discussed in this paper were presented at the Sacred Plants in the Americas Congress on February 2018, in Guadalajara, México. In addition, an earlier and less developed version of this article appeared in Spanish (Arce \& Rodríguez, 2018) in the blog of that same conference (https://drogaspoliticacultura.net/psa/consumo-de-plantas-y-hongospsicoactivos-en-las-culturas-precolombinas-de-costa-rica/).

** Corresponding authors: José M. Rodríguez; School of Anthropology, University of Costa Rica, Montes de Oca, San José 2060, Costa Rica; Phone: +506 8841 8283; Fax: +506 2223 3576; E-mail: jose.rodriguezarce@ucr.ac.cr; Marco A. Arce; Collections Management, Museums of the Central Bank of Costa Rica, Bajos de la Plaza de la Cultura, San José 10104, Costa Rica; Phone: +506 8869 6368; Fax: +506 2243 4220; E-mail: arcecm@ becr.fi.cr
}

This is an open-access article distributed under the terms of the Creative Commons Attribution-NonCommercial 4.0 International License, which permits unrestricted use, distribution, and reproduction in any medium for non-commercial purposes, provided the original author and source are credited, a link to the CC License is provided, and changes - if any - are indicated. 
lines of evidence (material culture, ethnographic references, ethnohistorical data, and paleobotanical remains); and second, to develop and test several hypotheses about the function and social location of this activity.

\section{COSTA RICA: A BRIEF ECOLOGICAL AND ARCHEOLOGICAL OVERVIEW}

The Central American isthmus contains an enormous biological and cultural richness. This is due in part to its place as an area of transition and interaction in geological, climatic, ecological, and cultural terms (Leigh, O'Dea, \& Vermeij, 2013). Its topography provides comfortable communication routes between both coasts: Caribbean and Pacific. This situation led to an intense exchange of people, materials, and ideas during ancient times (Joyce, 2013b). According to Geurds (2018), southern Central America is considered a key area for understanding human mobility, environmental adaptation, and long-distance exchange in the Americas and indeed from a global archeology perspective.

It goes without saying that the current geopolitical divisions that we know as Panama, Costa Rica, and Nicaragua do not correspond to the cultural units of pre-Hispanic southern Central America. This narrow territory has been home to a remarkable cultural heterogeneity for more than 12,000 years, being the environmental context for diverse trajectories of social change that led, in some cases, to the formation of complex chiefdom societies in the centuries before the arrival of European invaders (Arias \& Murillo, 2014; Geurds, 2018; Murillo \& Martín, 2017; Peytrequín, 2012).
Regarding the availability of bioactive materials in prehistoric times, the southern Central American natural landscape offered a great diversity of mood- and mind-altering plant and mushroom species (Fallas, 1972; Hammel, 2005; Hammel, Grayum, Herrera, \& Zamora, 2015). The most likely to have been employed by ancient indigenous populations include tobacco (Nicotiana spp.), cacao (Theobroma cacao), and morning glory (e.g., Turbina corymbosa, Ipomoea tricolor, and Ipomoea carnata). Fungi such as fly agaric (Amanita muscaria) and psilocybin mushrooms (e.g., Psilocybe mexicana and Psilocybe caerulescens) were also accessible (Mata, 2003). Moreover, various plants from which fermented alcoholic beverages of varying potency could be prepared were present: for example, maize (Zea mays), yuca (Manihot esculenta), coyol (Acrocomia vinifera), and pejibaye or peach palm (Bactris gasipaes) (Arford \& Horn, 2004; Blanco \& Mora, 1995; Peytrequín, 2012).

\section{Archeological regions of Costa Rica}

In Costa Rica, three archeological regions have been established based on geographical (mountain ranges, rivers, valleys, etc.) and cultural (settlements, burials, ceramics, and others) criteria. Within each region, there is a formal similarity in the material vestiges corresponding to different periods of occupation. Table 1 summarizes some general characteristics of each of the three archeological regions in terms of their geographical location, ecological, and archeological aspects, as well as the presence of evidence for the consumption of psychoactive plants and fungi. Figure 1 shows the approximate location on a map of Costa Rica of the archeological regions and sites mentioned.

Table 1. General information of the three archeological regions of Costa Rica

\begin{tabular}{|c|c|c|c|}
\hline & Greater Nicoya & $\begin{array}{c}\text { Central (Caribbean and } \\
\text { Central-Pacific subregions) }\end{array}$ & $\begin{array}{l}\text { Greater Chiriquí } \\
\text { (Diquís subregion) }\end{array}$ \\
\hline $\begin{array}{l}\text { Geographical } \\
\text { location }\end{array}$ & $\begin{array}{l}\text { It extends over part of Costa Rica } \\
\text { and Nicaragua. In Costa Rica, it } \\
\text { includes the current province of } \\
\text { Guanacaste and the northern } \\
\text { sector of the province of } \\
\text { Puntarenas }\end{array}$ & $\begin{array}{l}\text { It occupies the central portion of the } \\
\text { country, extending from the Pacific } \\
\text { coast to the Caribbean coast. There } \\
\text { are two subregions: Central-Pacific } \\
\text { and Caribbean }\end{array}$ & $\begin{array}{l}\text { It extends over part of Costa Rica } \\
\text { and Panama. The Costa Rican } \\
\text { sector includes the southwest of } \\
\text { the country, as well as the Atlantic } \\
\text { foothills of the Talamanca } \\
\text { mountain range }\end{array}$ \\
\hline $\begin{array}{l}\text { Main ecological } \\
\text { characteristics }\end{array}$ & $\begin{array}{l}\text { Plains and irregular coastal area, } \\
\text { with important gulfs; tropical } \\
\text { climate with two seasons: dry } \\
\text { and rainy; low annual rainfall; } \\
\text { semi-arid forests and tropical } \\
\text { wooded savanna }\end{array}$ & $\begin{array}{l}\text { Very diverse topography, with } \\
\text { important mountainous areas; } \\
\text { tropical rainy weather; high annual } \\
\text { rainfall; very humid tropical forests } \\
\text { and rain forests }\end{array}$ & $\begin{array}{l}\text { Very diverse topography, with } \\
\text { important mountainous areas and } \\
\text { irregular coast; tropical rainy } \\
\text { weather; medium annual rainfall; } \\
\text { very humid premontaneous forests }\end{array}$ \\
\hline $\begin{array}{l}\text { Main } \\
\text { archeological } \\
\text { characteristics }\end{array}$ & $\begin{array}{l}\text { Polychrome ceramics; jade and } \\
\text { obsidian artifacts; iconographic } \\
\text { influence from Mesoamerican } \\
\text { cultures. Mesoamerican } \\
\text { migration from } 800 \mathrm{CE}\end{array}$ & $\begin{array}{l}\text { Elaborate sculptural work (lithic), } \\
\text { monumental architecture, hydraulic } \\
\text { engineering, work in goldsmithing, } \\
\text { jade and gold artifacts, ceramics } \\
\text { with plastic motifs }\end{array}$ & $\begin{array}{l}\text { Stone spheres; elaborate } \\
\text { metallurgical work; polychrome } \\
\text { ceramics; elaborate sculptural } \\
\text { work; monumental architecture }\end{array}$ \\
\hline $\begin{array}{l}\text { Material culture } \\
\text { associated with } \\
\text { the use of } \\
\text { inebriants }\end{array}$ & $\begin{array}{l}\text { Ceramic pipes and inhalers, } \\
\text { mushroom-shaped ceramic } \\
\text { effigies, metate, or carved stone } \\
\text { ritual seat with fungiform } \\
\text { representation }\end{array}$ & $\begin{array}{l}\text { Charred morning glory seeds, } \\
\text { ceramic pipes and inhalers, ceramic } \\
\text { and lithic anthropomorphic effigies } \\
\text { of "smokers" and "thinkers" }\end{array}$ & $\begin{array}{l}\text { Gold Darién pendants and other } \\
\text { artifacts with mushroom-shaped } \\
\text { representations, gold, ceramic, } \\
\text { and jade poporo gourds for storing } \\
\text { quicklime }\end{array}$ \\
\hline
\end{tabular}




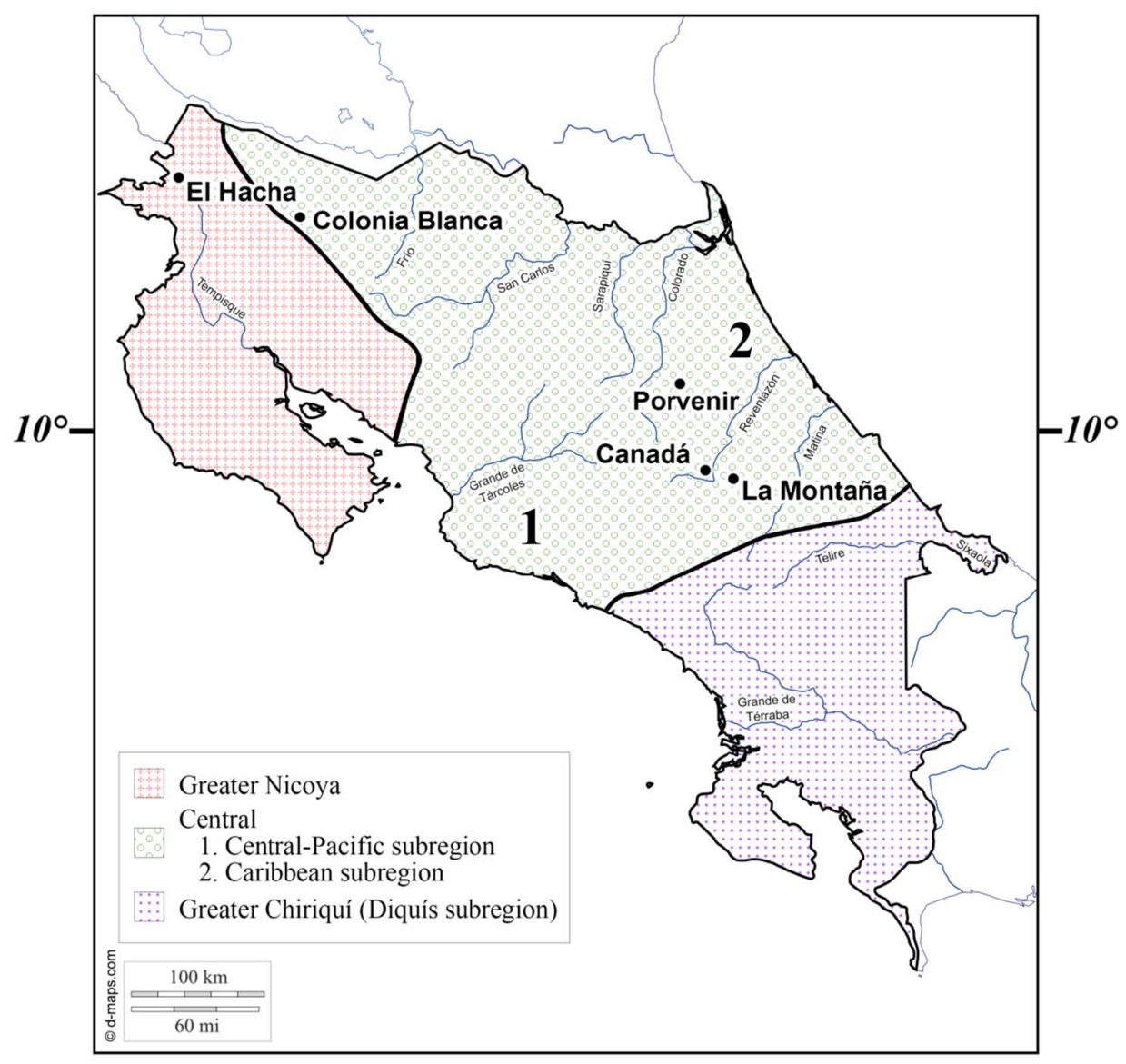

Figure 1. Map of Costa Rica showing location of the three archeological regions. Also shown are the sites mentioned in the text

\section{BACKGROUND: WHAT DO WE KNOW ABOUT THE USE OF MIND-ALTERING PLANTS AND MUSHROOMS IN COSTA RICA?}

For the current Costa Rican territory, the consumption of psychoactive substances in general has been documented in few occasions. The first evidence goes back to the 16th century in comments by Gonzalo Fernández de Oviedo and Valdéz concerning the reception of the cacique (highranking chief) Nambí on the night of August 19, 1529, that:

The cacique presented a handful of rolls of tobacco, about four inches long and the thickness of a finger, made of a certain rolled leaf and tied with fibers of pita. They cultivate tobacco with great care because of the effect produced by its leaves. They light the roll at one end and smoke it like a pipe until it stops burning, which can last a whole day. From time to time, they put in the mouth the opposite extremity to the one that is lighted and inhale the smoke a moment, and then throw it out through the mouth and nostrils. And each of the Indians I mentioned had of these rolled leaves, which they call yapoquete. (own translation of the excerpt in Fernández de Oviedo, 1851, p. 96)

This is the first explicit reference to tobacco consumption (Nicotiana sp.) in the Costa Rican North Pacific, and to one of the contexts of its use, namely a public celebration in which great quantities of maize (Z. mays) chicha (a fermented beverage) and cacao brew were drunk, and people sung and danced for hours in the presence of the chief and other high-status people who, also increasingly inebriated, sat on their dúhos (ceremonial seats), smoking tobacco at a designated location in the Nicoya plaza (Fernández de Oviedo, 1851). At this time, the hoe cultivation system was documented, where intensive grain agriculture was complemented with arboriculture. Some of the main crops cultivated were maize, tobacco, pita (Furcraea cabuya), and cacao (Ferrero, 1977). Cacao was drunk ceremonially, mixed with annatto (Bixa orellana) to give it a red tint similar to blood (Fernández de Oviedo, 1851).

Chroniclers found that among the Talamancan (Bribri and Cabecar) peoples of the Costa Rican Atlantic watershed, cacao was also a highly appreciated beverage. It was considered as the preferred drink to offer a friend, to give to people of importance, and to provide to the dead for their non-returnable journey (Stone, 1961). In Talamanca, fermented beverages were also valued. According to Gabb (1875), most of the maize produced in this region was used in the form of chicha (i.e., as a source of an inebriant, not a foodstuff). When a person wanted to clear a piece of forest for a plantation (usually of corn for making more chicha) or to build a house they needed to provide a suitable quantity of food and especially of chicha to convoke their neighbors for help (Gabb, 1875; Skinner, 1920). Actually, no labor could be accomplished without liberal allowances of this 
intoxicating drink, and the men who could provide the biggest quantities of it were held in high regard (Gabb, 1875). Chicha was also drunk at parties and ceremonies, and the favorite plant sources to prepare it were maize, yuca, and pejibaye (Stone, 1961).

Gabb (1875) also describes the use of tobacco by specific personages of the Bribri and Cabecar people, the awápa or shaman/healers. They employed it to diagnose and treat illnesses, an activity which often involved fumigating the patients with tobacco smoke and the use of sacred divination stones. These spiritual leaders also claimed to be able to control the weather and influence the luck of travelers by giving verbal orders while they smoked tobacco and blew the smoke in certain directions (Gabb, 1875). It seems the higher-status usêkölpa (great ritual specialists akin to priests) also employed tobacco in their ritualistic and ceremonial activities. Some of the myths of the Cabecars support this notion: for example, a sacred narrative that describes how a young and brave usêköl (the singular of usêkölpa) brought with him in a quest various cigars of tobacco to appease, and eventually capture and kill, an enormous and ferocious eagle that was hunting and devouring the inhabitants of the area, disturbing the peace and tranquility of the communities (Fernández, 2011; Stone, 1961). Moreover, tobacco was important for these politico-religious chiefs during war with the neighboring Teribes; apparently, they used the smoke to block and eliminate the senses of the enemy warriors, eventually making them fall asleep (Bozzoli, 1992; Fernández, 2011).

In all probability, not only Nicotiana tabacum was consumed during the contact period and in prehistoric times, but also the more potent wild tobacco (Nicotiana rustica; Wink \& van Wyk, 2008), given that it had reached Central America and Mexico (from its origins in the Andes) since at least 5,000 years BCE (Carmody, Caffrey, Lady, \& Horn, 2017). Tobacco was one of the preferred "power plants" or "plant teachers" used nearly everywhere in the Americas, where it is commonly associated with pipe ceremonialism and bird imagery (Wilbert, 1987; Winter, 2000). Unlike modern cured tobacco, some of the tobacco preparations consumed by the region's ancestral peoples (e.g., the rather large and bulky cigars that could last a whole day lit, described by Fernández de Oviedo) most certainly produced powerfully stimulating and perhaps even hallucinatory effects. It must be remarked that besides nicotine, which has hallucinogenic properties at high dosages (Wink \& van Wyk, 2008), tobacco species have also been found to contain traces of harmala alkaloids and myristicin, compounds with known psychedelic effects (Ferreira, Cruz, Vieira, \& de Albuquerque, 2010; Rätsch, 2005). There is no clear indication that during the contact period or afterward, tobacco (or any other plant, for that matter) was consumed for visionary purposes by either the awápa or the usekölpa. Nevertheless, a hallucinatory use of tobacco (and/or other psychoactive plants) might have been in place during prehistoric times, as is suggested by artifacts such as large-bowled pipes and nasal inhalers (see below); these implements provided much more efficient methods of administering the psychoactive principles in the ingested botanical material.

The first archeologist to study the material culture linked to the consumption of mind-altering plants was
Lothrop (1926), who referred to the existence of a few objects he identified as pipes with double nozzles (i.e., inhalers). Lothrop associates these artifacts with the "Y"-shaped tubes that were used for the purpose of nasally insufflating cohoba (Anadenanthera peregrina) snuff throughout the Greater Antilles and on the north coast of South America (Guerrero, 2012; Román, 2007). Stone (1966) also mentions the finding of small clay pipes with one or two stems, making reference to the possible consumption of cohoba mixed with tobacco. She describes these objects as characteristic of the Caribbean subregion and links them to the ceramic complex El Bosque (300 BCE-300 CE; Stone, 1977). It must be noted that A. peregrina does not seem to be native to Costa Rica; therefore, if cohoba seeds were used in ancient times they would have to have been brought from somewhere else, possibly from the Greater Antilles as an item of trade.

In 1945, Lines made a comparative analysis between the prehistoric material culture of the Atlantic watershed and the social practices of the Talamancan indigenous peoples, starting from the assumption that tobacco is linked with the training, as well as the healing and magical activities of the awápa and the usêkölpa. Lines (1945) proposed that a series of anthropomorphic stone sculptures that represent male characters kneeling down or sitting, sometimes described as "smokers" and/or "thinkers," are depictions of these (or analogous) ritual specialists in prehistory. Such sculptures present the character kneeling on one leg on which the hand rests, while the other arm is raised at the height of the head, inclined and projected forward. Often, the dorsal spine, vertebrae, and sexual organs (always male) are clearly portrayed, and the individuals are frequently depicted holding an object near the mouth or in contact with it, which has been interpreted by some as a cigar, and by others as a flute or a piece of food (Figure 2).

It is Lines (1954, p. 62) as well who provides the first description of the pipes and inhalers in his book "Taxonomy of the Archeology of Costa Rica," where he defines that: “. . a pipe is understood to be an instrument composed of: (1) a bowl or vertical chamber to burn the tobacco, and (2) a tube or stem to aspire the smoke through the mouth. There are also in Costa Rica some specimens with two tubes designed for nasal aspiration, in which tobacco in powder or snuff was probably consumed; and very rare conical nozzles that serve to hold a cigarette or cigar. All these specimens are extremely rare even though historical references reveal that our aborigines used tobacco with prodigality." This work is the first attempt to morphologically define these artifacts, and is the first attempt to understand them starting from their form in order to interpret their function. It must be acknowledged that, unfortunately, in Costa Rica, a majority of the records of inhalers and pipes are not archeologically controlled.

For the Costa Rican North Pacific, Stone (1977) mentions the finding of a mushroom-shaped red vessel that presents incised designs on the body (similar to those in Figure 3), in a cemetery at the El Hacha site, located near the Coyol River. This artifact becomes the first finding linked to the possible use of mind-altering fungi in the Greater Nicoya region. Later, Jones (1991) proposed that additional artifacts from this region point to the processing and consumption of 

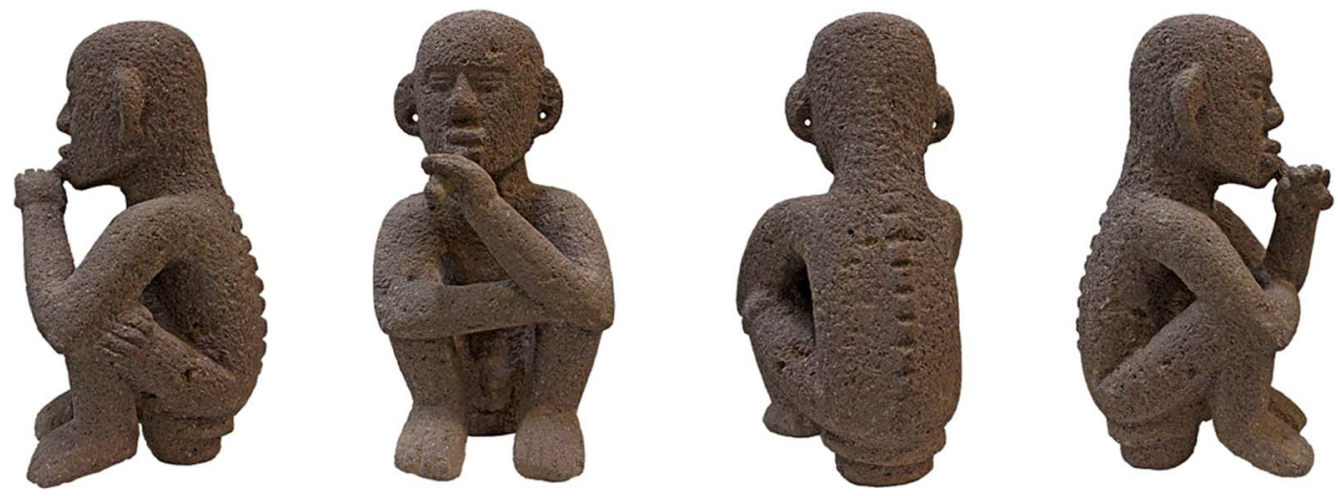

Figure 2. Various views of a stone sculpture of a personage described as a "thinker" and/or "smoker," sitting on a stool, holding what appears to be a cigar, $31 \mathrm{~cm}$, National Museum of Costa Rica, no. 8272. It probably represents the consumption of tobacco by a ritual specialist

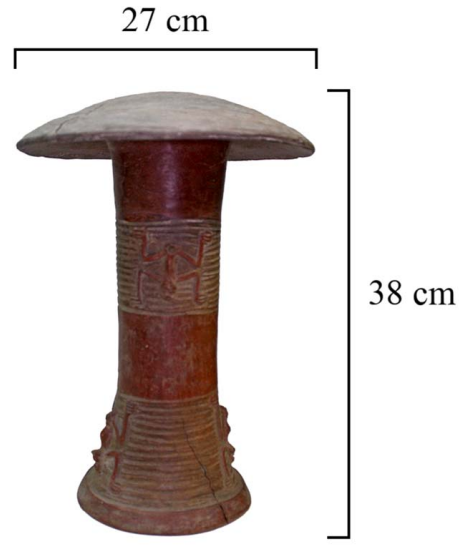

(a)

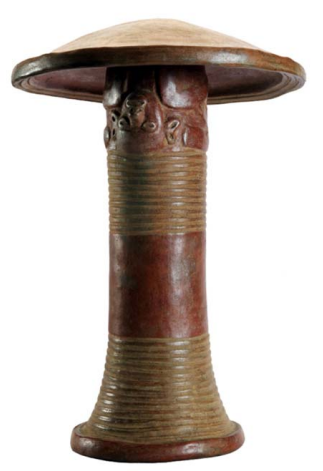

(b)

Figure 3. Mushroom-shaped elements in ceramic artwork. They may allude to the consumption of mushroom species with psychedelic properties. Both artifacts were found in the Greater Nicoya region and have similar dimensions. (a) Mushroom-shaped ceramic sculpture, National Museum of Costa Rica, no. 1458;

(b) mushroom-shaped ceramic sculpture, Museum of Jade y PreColumbian Culture, no. 477 (after Gómez, n.d., p. 35)

psychedelic mushrooms. She bases her argument mainly on an interpretation of material culture: the fungus effigy described by Stone at El Hacha site, and a tripod carvedstone platform for either grinding or sitting (or both) that has an anthropomorphic figure flanked by two perforated semicircular elements that she identifies as the fly agaric (A. muscaria) hallucinogenic mushroom (Figure 4). The identification of A. muscaria, as opposed to other psychedelic mushroom species, is based on the spot-like perforated features exhibited on the two flanking semicircular elements. These spotted semicircular motifs appear to represent the characteristic white-scaled red caps of the fly agaric mushroom.

It must be mentioned that $A$. muscaria does not grow in this part of the territory, which is mainly composed of lowlands and has a rather dry climate. Thus, if it was ingested in the North Pacific, it would have to have been brought from a different place, perhaps (dried) from the highlands of the Central region where this type of mushroom grows in association with pines and ericaceous plants (Mata, 2003).
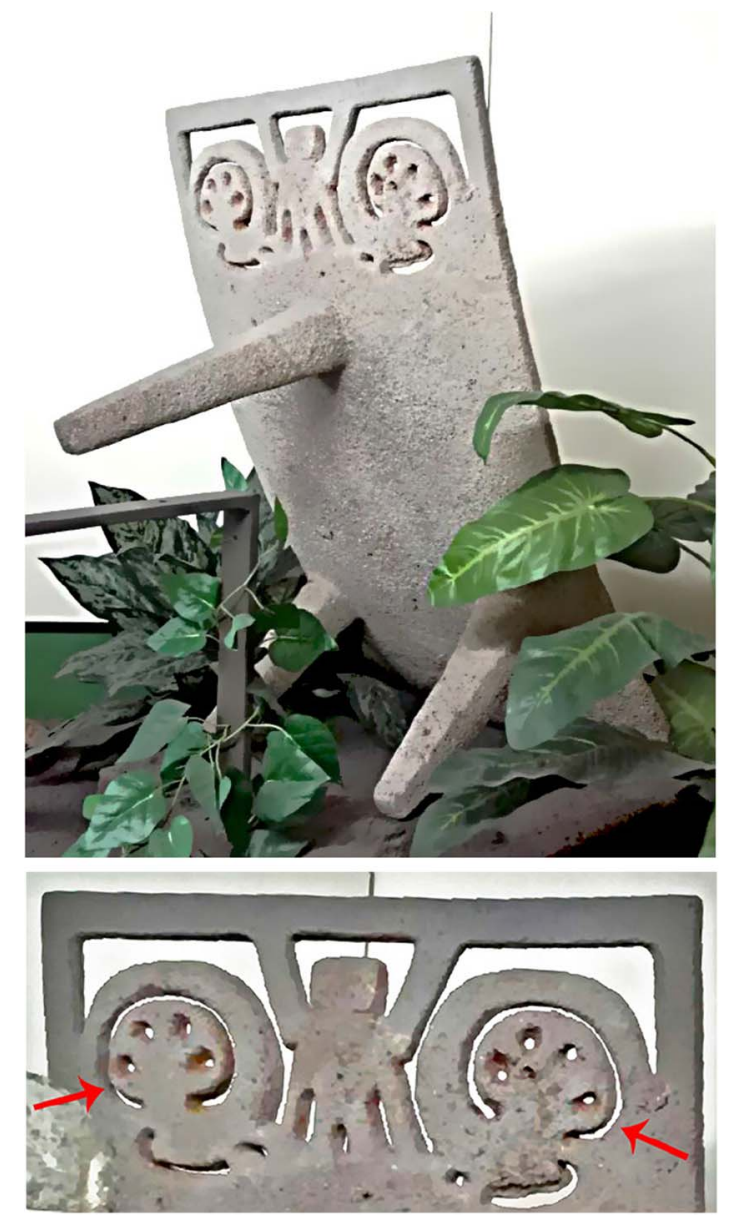

Figure 4. Bottom view and detail of a tripod rectangular stone metate or seat with a carved anthropomorphic design at one of its ends, $97 \mathrm{~cm}$, National Museum of Costa Rica, no. 32065. The

mushroom-shaped elements depicted may allude to the consumption of psychoactive fungi species, specifically, the fly agaric (A. muscaria) mushroom

More recently, the archeologist Vázquez (2002) reports on the excavation of a relatively large pipe and a deep bowl, found one inside the other in a corridor tomb, at the Canadá site. This site corresponds temporally to the El Bosque period (300 BCE-300 CE), and is located in the Caribbean subregion. The author proposes that this site corresponds to 
a sacred site where previous funerary spaces were respected. Vázquez (2010) also makes an interpretative effort to infer the possible altered state of consciousness of a character carved in stone in the Colonia Blanca site, on the northern zone of Costa Rica. In this petroglyph, some facial features are interpreted as a representation of the effects caused by the consumption of some psychoactive substance. For example, the face presents round and exorbitant eyes as well as a wrinkled forehead, cheeks, and mouth that the author interprets as bodily reactions consistent with the consumption of a powerful stimulant or hallucinogen, most likely tobacco. Moreover, Vázquez (2010) interprets a series of lines and zoomorphic designs that stem from the head backward as representing a vision constituted by bird motifs (mainly hummingbirds and king vultures). He associates these with the strong mental effect of lightness that accompanied the inebriated state. Again, pipes and inhalers are mentioned as the most likely vehicles for the intake of the sacred plant, probably wild tobacco.

Finally, there are a number of paleobotanical findings that suggest the use of psychoactive plants and inebriating beverages in prehistoric times. Snarskis (2009) mentions that morning glory seeds (Ipomoea sp.) were recovered in a layer of carbonized floral remains in two bell-shaped storage pits, later used as refuse dumps at the Barreal de Heredia archeological site, located in the Central region. Numerous species of this genus are known to contain psychedelic ergot alkaloids such as lysergic acid amide (Wink \& van Wyk, 2008). At least five species with mindaltering properties are native to Costa Rica (Hammel et al., 2015). Blanco and Salgado (1980) published the only scientific paper written about this archeological site and confirm the recuperation of macrobotanical remains; however, they do not delve into the type of flora identified in the burned vestiges.

Regarding the cultigens traditionally employed for the preparation of chicha, in situ botanical inventories in the Sarapiquí and Arenal locations, both in the Central region, support the notion that maize and pejibaye have been cultivated for about 4,000 and 2,500 years, respectively (Arford \& Horn, 2004; Blanco \& Mora, 1995).

\section{METHODS}

The use of psychoactive materials in traditional premodern cultures is part of the response to various biological and social needs. These include, for example, maintaining homeostasis and overcoming disease (Forbey et al., 2009; Villalba \& Provenza, 2007); the innate drive to experience modified states of consciousness (Cardeña \& Winkelman, 2011; Siegel, 2005), as well as the need to establish and maintain social groups and networks (Müller \& Schumann, 2011). The archeological artifacts linked to the consumption of mind-altering plants and mushrooms are the material expression of these responses. The steps followed in this investigation sought to identify the social practices of ingesting psychoactive substances based on the material remains of pre-16th-century Costa Rican human groups, the ultimate goal being to explore the cultural significance of these practices.
To aid the process of inferring the possible uses and meanings of the material culture examined, several lines of evidence were employed: the study of the recurrence of certain motifs in similar situations, such as funerary offerings, the texts left by the Spanish during the 16th and 17th centuries, as well as by naturalists during the 19th century, and the spiritual beliefs still maintained by the indigenous peoples of Costa Rica.

First, a literature review of primary and secondary sources (Bozzoli, 1992; Fernández, 2011; Fernández de Oviedo, 1851; Ferrero, 1977; Gabb, 1875; Jones, 1991; Lines, 1945, 1954; Lothrop, 1926; Pittier, 1938; Skinner, 1920; Snarskis, 2009; Stone, 1961, 1966, 1977; Vázquez, 2010) was performed in order to integrate the ethnohistorical, ethnographic, archeological, and paleobotanical information available regarding the use of mind-altering plants and mushrooms in Costa Rican extant and extinct cultures. This information allowed us to partially reconstruct some of the native drug-using practices that were encountered by the European conquerors and later chroniclers, and that in a few cases continue to this day. We identify the existence of a number of artifacts and ecofacts that can be linked, with various degrees of certainty, to the ancient consumption of psychoactive materials. The meticulous recovery of some of these objects, properly registering their circumstances of deposition, makes them prime sources of contextual and, with a bit of luck, paleobotanical and chemical information.

Second, a further identification and selection of materials was performed. In order to trace the consumption of psychoactive substances in prehistoric Costa Rica, there are three different categories of archeological documents that can potentially be used: macro- and microfossil remains of psychoactive plants (e.g., burned seeds and starch granules), psychoactive alkaloids in archeological artifacts, and artistic depictions of mind-altering plants and mushrooms (or their consumption). No study of psychoactive alkaloids in ancient objects has been performed yet, and very few paleobotanical findings have been reported in the literature. Therefore, the emphasis was placed on selecting and examining types of artifacts presumed to be associated with the use of inebriating substances (especially objects required to prepare and consume them), and that could eventually yield archeobotanical material or psychoactive residues. Besides that, artistic depictions of mind-altering species or of their consumption were also considered.

Therefore, in addition to the archeological documents identified through the literature review, an exhaustive search was carried out in the collections of the Museums of the Central Bank of Costa Rica and the National Museum of Costa Rica with the objective of identifying artifacts with a possible linkage to the consumption of psychoactive plants and mushrooms. The list of types of objects to be looked for was elaborated based on the model of the indigenous practices associated with inebriation developed in the first step through the literature review, by ethnographic analogy with nearby and related cultures such as the Taíno (Guerrero, 2012) and the Kuna (Fortis, 2015) (for which the ethnographic sources are much more rich and detailed), and by using as parameters or starting points the ethnographic and historic information on a regional and continental scale. The materials included in the list were: molded, fired-clay 
pipes and inhalers, stone and ceramic sculptures of "smokers" and "thinkers," ceramic vessels, carved stone grinding platforms (metates) or seats, and gold pendants with mushroom-shaped motifs, as well as ceramic and gold poporo gourds. A total of 46 artifacts were selected to be analyzed and categorized taking into account the nature of their material (raw origin matter), morphology, dimensions, provenance, and relative chronology.

\section{ARCHEOLOGICAL EVIDENCE OF THE CONSUMPTION OF PSYCHOACTIVE SUBSTANCES IN ANCESTRAL COSTA RICA}

\section{Greater Nicoya region}

In the Greater Nicoya region, there are various types of artifacts that suggest the consumption of psychoactive materials during the pre-Hispanic era, namely: ceramic effigies whose morphology resembles that of a mushroom (Figure 3), a carved stone tripod metate that presents a pair of skillfully carved mushroom-shaped designs (Figure 4), ceramic inhalers with anthropomorphic as well as zoomorphic motifs (Figure 5), and anthropomorphic and zoomorphic pipes also made out of clay. Some of the characteristics of these objects were already discussed earlier in the "Background" section.

Therefore, the material culture identified for this region indicates two possible traditions of psychoactive drug consumption: one related to the intake of fungi, and a second one associated with the smoking and snorting of psychoactive plant material.

Regarding the presumed tradition of psychoactive mushroom use, it is unclear if the species portrayed is A. muscaria, as is suggested by Jones (1991). The features in the stone metate that she posits correspond to the fly agaric ("spots" on the cap reminiscent of the scales or universal veil remnants usually found on the surface of the pileus; see detail in Figure 4) are absent in the ceramic mushrooms, which present a rather smooth surface on the top of the cap, perhaps more reminiscent of psilocybin mushrooms (Figure 3). Both the caps of $A$. muscaria and of certain psilocybin mushrooms have a convex form, so the shape of the cap in the ceramic vessels does not seem to be a very informative characteristic. Unfortunately, additional distinguishable features that could prove useful in discerning the specific type of fungi depicted are lacking.

Nevertheless, it can be argued that some form of "mycolatry" existed, given that there are at least three mushroomshaped effigies in addition to the metate or ritual seat with the stylized mushroom motifs (Jones, 1991; Stone, 1977). In addition, one of the ceramic fungiform vessels was excavated at a gravesite in association with carved jade symbolic objects; according to Stone (1977), this may imply the existence of some type of "religious cult" (whose precise nature remains unspecified). Both the mushroom vessels (ceramic-type Bocana Inciso, Diría variety) and the metate were manufactured around the same time, being associated with the Tempisque phase (500 BCE-500 CE).

In regard to the second tradition, the plant most probably consumed was tobacco, both orally and nasally. Further biochemical and starch granule morphology analyses of botanical material recovered in the inhalers' stems, and bowls will allow us to determine if DMT-containing cohoba powder was also consumed. It must be noted that the cohoba hypothesis is indirectly supported by the presence in this region of a carved-bone emetic spatula (V. Novoa, personal communication, February 13, 2019), an ergonomic vomitinducing instrument that is indistinguishable from those found in the islands of the Caribbean, and which is a typical constituent of the paraphernalia associated with the cohoba cult among the Taíno (Guerrero, 2012).

The dating of the artifacts indicates their use occurs between the years $300 \mathrm{BCE}$ and $900 \mathrm{CE}$. The consumption of psychoactive plant material is evident in the archeological record starting from the Tempisque period (300 BCE-500 CE). Here, nasal inhalers with zoomorphic representations, identified as the ceramic-type Marbella with punched impressions in zones (Figure 5c), were relatively common. This tradition seems to change in the form of consumption as the habit of inhaling is temporarily abandoned and the practice of smoking takes hold during the Bagaces period (400-900 CE) when the presence of

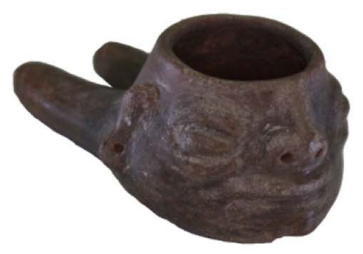

(a)

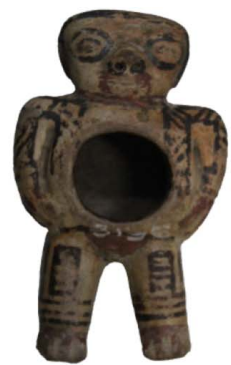

(b)

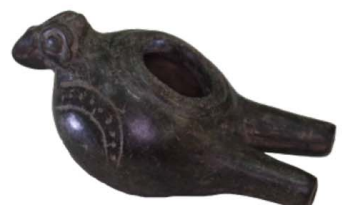

(c)

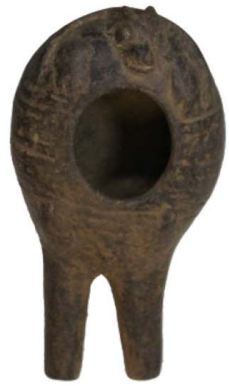

(d)

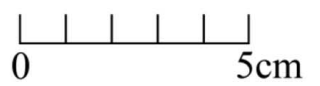

Figure 5. Anthropomorphic and zoomorphic elements represented in ceramic nasal inhalers of the Greater Nicoya region. They are evidence of the consumption of tobacco and, probably cohoba snuff. (a) Nasal inhaler, National Museum of Costa Rica, no. B339; (b) nasal inhaler, National Museum of Costa Rica, no. 3196; (c) nasal inhaler, National Museum of Costa Rica, no. 27080; (d) nasal inhaler, National Museum of Costa Rica, no. 27079 
pipes was recorded. Afterward, between ca. 800 and $900 \mathrm{CE}$, during the Sapoá period, anthropomorphic nasal inhalers are again found in archeological contexts, which could evidence a return to practices associated with the insufflation of snuff. Some of the inhalers for this period are beautifully crafted, as is evidenced by those categorized as belonging to the Mora Polychrome variety, Guabal type (Figure 5b). After ca. $1200 \mathrm{CE}$, and considering the chronicle of Fernández de Oviedo in 1529, it is possible that tobacco was consumed mainly by smoking large cigars wrapped in leaves.

\section{Central region}

In the Central region (particularly in the Caribbean subregion), there are also a variety of artifacts that suggest, in both direct and indirect manners, the consumption of psychoactive substances during the pre-Columbian era. These include a series of anthropomorphic effigies of "smokers" elaborated in ceramic material (Figure 6), anthropomorphic stone sculptures of "smokers "and "thinkers" (Figure 2), snuff inhalers, some with anthropomorphic and zoomorphic designs (Figure 7), and plain smoking pipes (Figure 8).

Thus, the material culture recovered shows the presence of a tradition of tobacco consumption during the El Bosque period, between ca. $300 \mathrm{BCE}$ and $300 \mathrm{CE}$, evidenced in ceramic figurines depicting characters smoking with pipes of the El Bosque Red type (Figure 6), nasal inhalers with anthropomorphic (Figure 7), and ornithomorphic motifs of the El Bosque Red on Buff type, in addition to pipes of the El Bosque Red and El Bosque Red on Buff (Figure 8). This type of material evidence is not only a clear indicator of the consumption of psychoactive plant material but also allows us to differentiate two types of consumption or methods of administration, namely, smoking and nasal inhaling. Ceramic inhalers have been excavated at La Montaña and Porvenir sites, in the Caribbean subregion; however, a proper archeological recording and reporting of the placement of the artifacts and their context is not available. Both sites temporarily correspond to the El Bosque period (300 BCE-300 CE).

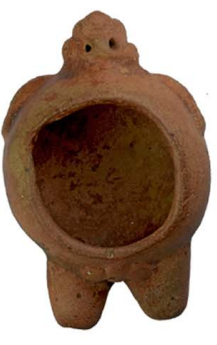

(a)

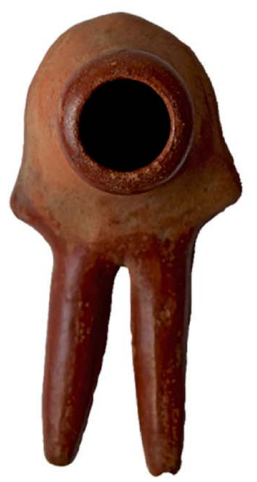

(c)

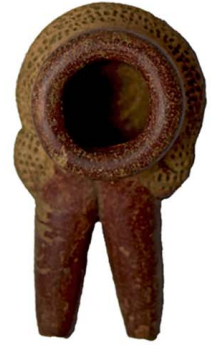

(b)

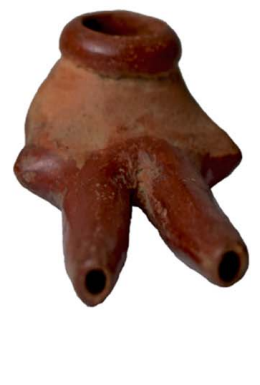

(d)

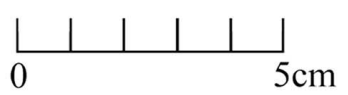

Figure 7. Ceramic inhalers found in the Central region. They were used to inhale tobacco snuff and, perhaps, cohoba. Some of them present a stylization of the human body; many are slip-coated and have a burnished finish. (a) Nasal inhaler, Museums of the Central Bank of Costa Rica, BCCR-C-532; (b) nasal inhaler, Museums of the Central Bank of Costa Rica, BCCR-C-528; (c and d) nasal inhaler, Museums of the Central Bank of Costa Rica, BCCR-C-524

For the La Selva phase and the Madera complex (300$1100 \mathrm{CE}$ ), there is a gap in the material culture linked to the consumption of inebriants as it is not found until the La Cabaña phase (1100-1500 CE) that a discernible presence in the material record again becomes apparent. Specifically, there are stone sculptures that represent kneeling or seated

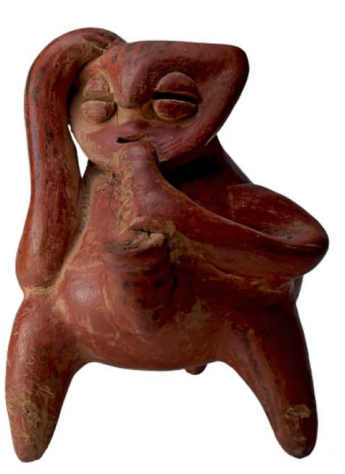

(a)

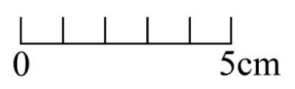

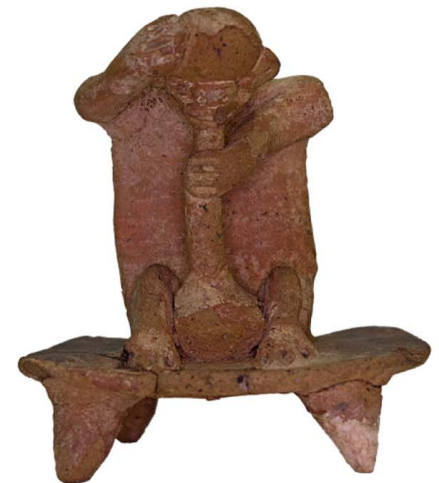

(b)

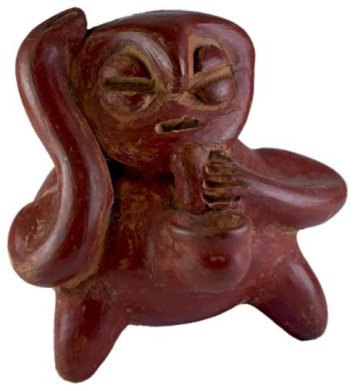

(c)

Figure 6. Ceramic effigies of individuals smoking with pipes. The hand resting over the head may be a sign of the powerful mind-altering effects of wild tobacco. (a) Ceramic sculpture, Museums of the Central Bank of Costa Rica, BCCR-C-552; (b) ceramic sculpture, National Museum of Costa Rica, no. 24187; (c) ceramic sculpture, Museums of the Central Bank of Costa Rica, BCCR-C-553 


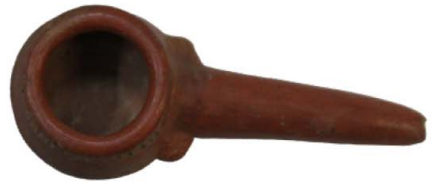

(a)

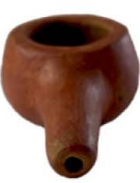

(b)

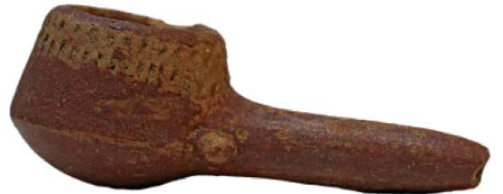

(c)

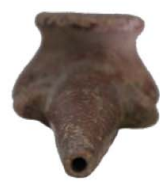

(d)

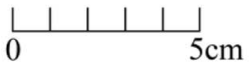

Figure 8. Ceramic pipes from the Central region. They were probably used to smoke tobacco. Some have considerably large bowls that could hold great quantities of plant material. Many specimens are slip-coated and have a burnished finish. (a) Ceramic pipe, National Museum of Costa Rica, no. 25421; (b) ceramic pipe, Museums of the Central Bank of Costa Rica, BCCR-C-521; (c) ceramic pipe, Canadá site, Caribbean subregion, National Museum of Costa Rica, no. 297; (d) ceramic pipe, National Museum of Costa Rica, no. 25740

characters with certain corporal characteristics that might be linked with malnutrition (possibly caused by fasting and other ascetic practices) such as protruding ribs and backbone, and a greater proportion of the head with respect to the body (Figure 2). Some are seated on stools, and in most cases these sculptures present elongated objects, possibly cigars that they hold with one or both hands, and which are set close to the mouth.

These lithic sculptures seem to indicate a transformation in the method of administering tobacco, abandoning the artifacts used in previous phases such as inhalers and pipes, and replacing them with cigars. This shift is also evidenced in the disappearance of the ceramic sculptures of individuals smoking from pipes, in conjunction with the disappearance of pipes and inhalers from the archeological record. Moreover, the bodily traits described suggest that they are representations of ritual specialists, akin to the awápa and/or usêkölpa of the Bribri and Cabecar who usually underwent periods of fasting and other types of deprivation during their training to become medicine men and magicoreligious authorities (Bozzoli, 1992; Jara \& García, 2003; Lines, 1945).

\section{Diquís subregion}

Finally, for the Diquís subregion, in the southeast of the country, there are a few artifacts that suggest the presence of the use of inebriants in the past, namely: gold pendants (Figure 9) and rattles with fungiform decorations, and small flask-like gourds for storing quicklime - known as poporos made both in gold and ceramic.

In the case of this particular subregion, it should be noted that artifacts related to the possible consumption of psychoactive substances are recorded starting from ca. $750 \mathrm{CE}$, the most notable being an anthropomorphic gold pendant with mushroom-shaped motifs of the style known as Darién (Figure 9). These objects have suspension hooks with apparent signs of wear that indicate their use as pendants. They were manufactured in gold and tumbaga (an intentional alloy of gold and copper), were elaborated with the lost-wax casting method, and have been unearthed more frequently in occidental Colombia, in the Sinú area (Torres, 2006). According to Falchetti (1979), two pendants found in the Cenote at Chichén Itzá are stylistically related to Costa Rican specimens, and were probably manufactured in this territory. Several authors (e.g., Emmerich, 1965; Pérez de Barradas, 1954; Schultes \& Bright, 1979) have suggested

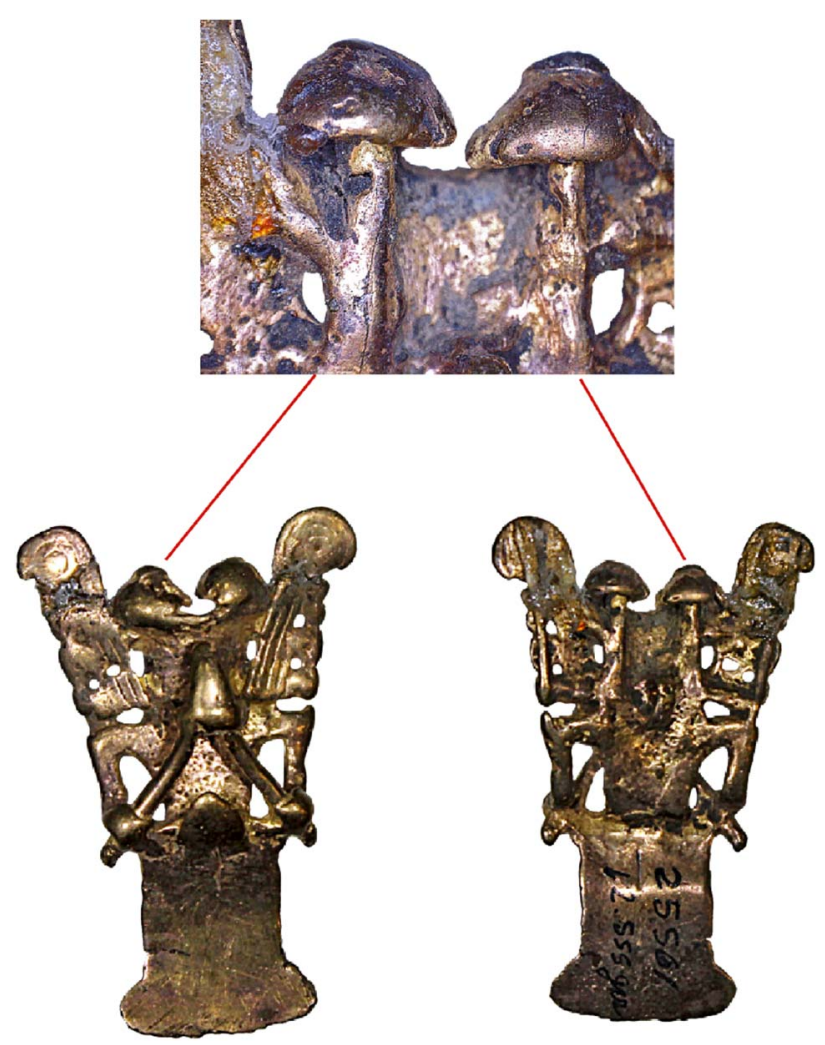

Figure 9. Front and back views of a Darién gold pendant with close-up of central fungiform motifs, National Museum of Costa Rica, no. 25561. The craftsmanship in this particular artifact is of relatively low quality in comparison with those found in Colombia (see, e.g., Torres, 2006, Fig. 1).

the hemispherical elements that form part of the headdress at the top of the Darién pendants represent psychedelic mushrooms. The persistence of a stipe below the hemispherical caps (despite it not being technically necessary), the presence of a sharp umbo (a nipple-like protuberance at the top of the pileus), and the shamanistic symbolic motifs present reinforce this interpretation (Torres, 2006).

On the other hand, the gold container (poporo) is comparable to certain objects found also in Colombia, and that have been identified as a typical element of the paraphernalia associated with the coca (Erythroxylum coca) cult. This device is employed to store the quicklime that is chewed along with the coca leaves in order to 
enhance the release of the active alkaloid principles in it (Helmreich, 1975). The poporo is used by present indigenous cultures in South America; for instance, the Kogis of the Sierra Nevada use them to carry quicklime prepared from crushed seashells (Reichel-Dolmatoff, 1953). Moreover, poporos are present in archeological contexts (Field, 2012), being characteristic of the Quimbaya metallurgic tradition (Torres, 2006). Returning to the Diquís subregion, it is important to mention that this object could be the result of economic exchange because it corresponds to a unique find for Costa Rica (P. Molina, personal communication, February 18,2018). There are other similar objects, which are exhibited in the Museum of Jade and PreColumbian Culture, but they are made of ceramic and jade. It is also possible that this type of implement is so scarce in the archeological record because the majority of them were manufactured with perishable materials (such as wood) that are usually not preserved in the humid conditions of tropical regions.

The material culture unearthed in this region indicates the consumption of psychoactive materials in the South Pacific of Costa Rica was late and could be partially the consequence of contact with cultural groups from other regions. Specifically, in relation to the use of coca, this influence might have come from South American cultural groups such as those located in the territories that today we know as Panama and Colombia. It is possible that coca leafs were ingested, and that the way of consumption was chewing them in conjunction with lime that was presumably kept and carried in the poporos. Regarding the alleged tradition of psychedelic fungi consumption, Torres (2006) suggests it may have been introduced from Mesoamerica at a time of increased exchange of ideas and materials in the region in general.

\section{DISCUSSION}

\section{What does the material evidence tell us about the use of psychoactive plants and mushrooms in ancestral Costa Rica?}

The diverse material evidence recovered from multiple archeological sites in the current Costa Rican territory supports the notion that psychoactive plants and mushrooms, as well as various inebriating and invigorating beverages, were consumed in prehistoric times. It is highly probable that tobacco, chicha, and cacao consumption was present throughout the entire territory. Evidence regarding morning glory seeds use is limited and restricted to the Central Valley. There exists the possibility that cohoba was consumed in the Caribbean and the North Pacific of Costa Rica, assuming it was obtained as an item of trade with cultural groups from the Greater Antilles such as the Taíno. Finally, there is sparse evidence for the ingestion of different types of psychedelic mushrooms in the North and South Pacific areas of this territory.

At least in the period between roughly 300 BCE until 300 $\mathrm{CE}$, it is clear that there was a significant ritualized and socially codified consumption of some of these inebriants in the Greater Nicoya region and Caribbean subregion (that continued to be relatively important much later; Figure 10). This is inferred mainly from the increased visibility in the archeological record of artifacts - some of them symbolically laden with anthropomorphic and zoomorphic designs - that are explicitly and functionally linked with the activity of consuming psychoactive plant material, namely, pipes and inhalers. Most of these implements of use (the ones examined here as well as those described in the literature) have been relatively dated to this period (known as the Tempisque period

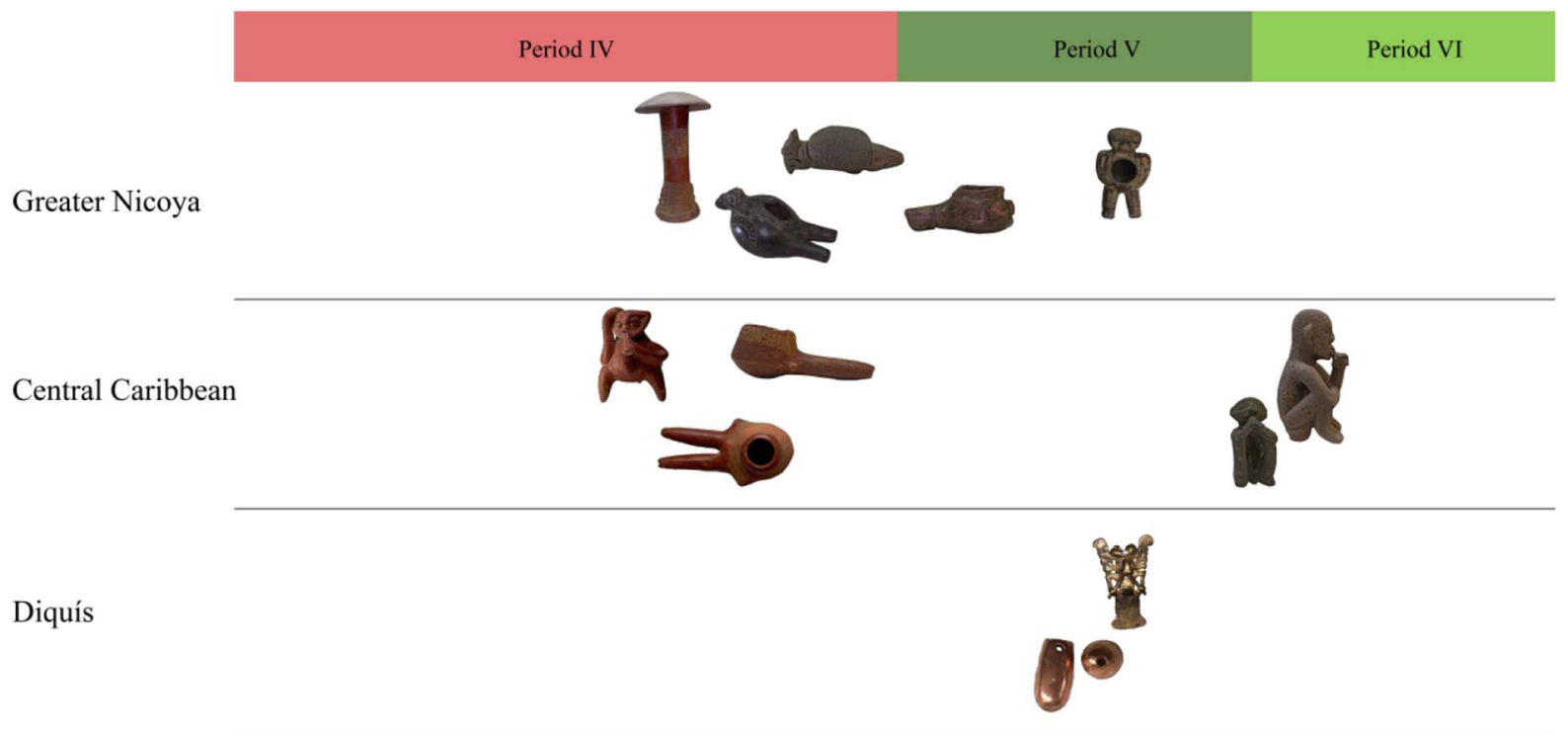

$1000900800700600500400300200100 \quad 01002003004005006007008009001000110012001300 \quad 14001500$

Figure 10. Simplified chronology of the consumption of psychoactive plants and mushrooms in ancient Costa Rica as it is inferred from archeological remains. During the last centuries of Period IV, a time of budding sociopolitical development, there seems to have been an increase in the use of consciousness altering substances in the Greater Nicoya and Central regions. At the end of Period V and during Period VI, psychoactive drug use in chiefly ranked societies is also attested by various types of material vestiges such as polychrome ceramic inhalers, stone sculptures of "smokers," and gold Darién pendants and poporos 
in Greater Nicoya and El Bosque period in the Caribbean subregion, and regionally as Period IV). The standardized nature of this ritual paraphernalia points to a rising social importance of the magico-religious activities performed as part and context of the consumption of psychoactive plant material.

It is noteworthy that based on archeological data, it is during this time that incipient sociopolitical formations emerge and material culture starts to diversify (Geurds, 2018). This period witnessed a remarkable increase in sites and population, sedentism, agriculture, and ceramic and lapidary (jade ornaments) production, coupled with a trend toward social stratification (Arias \& Murillo, 2014; Fonseca, 2003; Snarskis, 1978). Moreover, ritual activity became exceptionally important throughout this period, as is evidenced in the diverse ceremonial objects produced, including implements such as rattles, whistles, maracas, and ceramic stamps (Fernández, 2013) presumably used to decorate the bodies of the ritual specialists or of the participants in the rituals they officiated (Fernández, 2004). According to Stone (1977), hollow zoomorphic and anthropomorphic figurines, ocarinas, as well as pipes and inhalers, all manufactured in fired-clay are also characteristic of this period.

Fernández (2013) has pointed out that most of these kinds of objects have been encountered as part of funerary offerings for the burials of individuals considered possibly to have been shamans or other magico-religious practitioners. The totality of artifacts presumed to be related to psychoactive drug use discussed here for which information is available about the archeological context in which they were excavated were also recovered in funerary contexts, that is to say, in tombs. Interestingly, the mushroom-shaped pottery vessel from El Hacha was unearthed at a gravesite in association with several sophisticated jade effigies with ornithomorphic and anthropomorphic motifs (Stone, 1977). This may imply that this burial belonged to some kind of high-status ritual specialist, if we take into account the prestige nature of jade goods (see below). Future excavations in additional primary contexts might reveal an association of pipes and/or inhalers with other shamanic tools such as diverse noisemakers, staffs, and ceramic stamps, which would lend further support to the idea that psychoactive drug use was linked to ritual activities.

An interesting feature of some of the inhalers examined is the presence of evident signs of wear in an orifice through which a rope was passed in order to wear it as a pendant (Figure 11). Certainly, this entailed the utilitarian benefit of allowing a way for the person to carry around the object. But this also means that at least some of these objects were employed as part of visible attire that was displayed publicly (perhaps only at certain designated times, and by the highest ranking spiritual leaders). It is known that jade objects, as well as objects made in other materials to which special properties were ascribed (e.g. gold), had a high symbolic and economic value and therefore were acquired only by certain individuals to demonstrate their prestige and power (Hoopes, 2013). These and other kinds of artifacts were also worn as part of the ornaments and insignia of the people who held positions of religious and political importance within society (Fernández, 2013). Therefore, following this line of

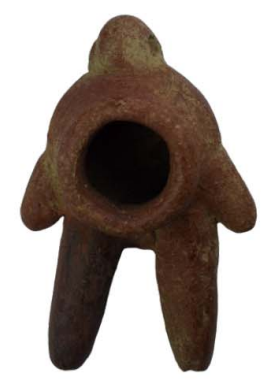

(a)

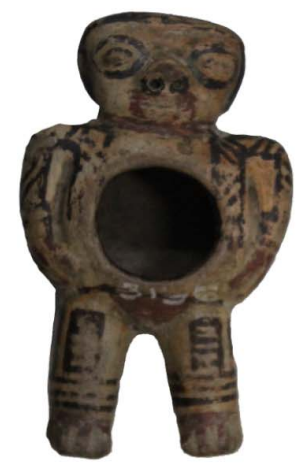

(c)

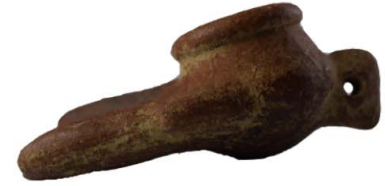

(b)

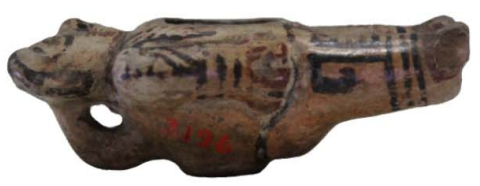

(d)

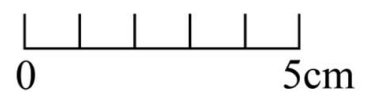

Figure 11. Ceramic inhalers with an orifice used to thread a rope and wear it as a pendant. ( $\mathrm{a}$ and $\mathrm{b}$ ) Front and lateral views of nasal inhaler, Museums of the Central Bank of Costa Rica, BCCR-C530; (c and d) front and lateral views of nasal inhaler, National Museum of Costa Rica, no. 3196

reasoning, it is suggested that a subset of the inhalers were employed not only to consume drug material but also as insignia or indicators of political and ceremonial rank that identified certain ritual specialists, and reinforced their authority by symbolizing a direct connection with the sacred. Concomitantly, these objects might have signaled the membership to a specific clan, since they possessed a hereditary nature and were bequeathed only in specific families, within members of particular clans (Ibarra, 1999). It is worth mentioning that none of the pipes examined so far have the orifice for threading a rope, excluding the possibility that they were worn as part of attire.

In regard to the tradition of tobacco consumption, it is noteworthy that a change in ingestive behaviors seems to have occurred starting from around $900 \mathrm{CE}$ in the Greater Nicoya and the Central regions. In both, there is a marked decrease in the production of specialized ceramic objects (pipes and inhalers) for the consumption of plant material and an apparent increase in the use of cigars to ingest tobacco. This cultural change seems to be attested too in the stone sculptures of "smokers" found in the Costa Rican Caribbean, and is also suggested by the chronicle of Fernández de Oviedo (1851), in 1529, who describes the smoking of tobacco via cigars wrapped in certain type of leaves in the Greater Nicoya region. This transformation may be evidence of a change in the types and functions of the altered states of consciousness sought, perhaps rooted in a shift from original shamanic activities (such as healing 
and divination, more typical of the awápa) to more derived priestly activities (such as propitiation of supernatural beings and rites for protection, performed by the usekölpa). There is also the possibility that the pipes and inhalers were still produced during these periods of time, but were instead elaborated using perishable materials that ultimately left no trace in the archeological record (e.g., bone and wood).

On another subject, with respect to the mushroom-shaped ceramic vessels of the Greater Nicoya region, it is necessary to allude to some data threads that inform our interpretation that they are cultural elements once linked to the intake of psychedelic mushroom species. As far as we know, even though psilocybin mushrooms are widely distributed throughout Costa Rica, there are no historical or ethnographic records of their ritual consumption. Not much is known about the edible fungi used in this region, either. There exists the possibility that the effigies are a representation of mushrooms that were part of the gastronomic or medical tradition. Another alternative is that they are not representations of mushrooms at all, and their form actually reflects the fact that they were utilitarian artifacts used as pottery molds, as Köhler (1976) has suggested for some of the famous Mesoamerican stone and ceramic mushrooms first described by de Borhegyi (1961, 1963). From this perspective, these objects had the practical function of serving as a convex mold used as part of an initial step in more elaborate techniques, for example, for making the base of a vessel or in fashioning vessels with a narrow neck (Köhler, 1976). Lowy (1982) raised several major objections to this potters' molds hypothesis.

However, there is no record of the employment of such fungiform artifacts in the pottery production techniques known for ancient Costa Rica (Snarskis, 1983), and the artifacts alluded to by Köhler are small and of a rather crude manufacture (which certainly seems to support a utilitarian interpretation). In contrast, the specimens found in Greater Nicoya are of larger dimensions (about $40 \mathrm{~cm}$ in height), lack use-wear traces, and were made with a well-refined manufacturing technique that incorporates rolls, burnished areas, and white paint in grooves (Figure 3). Such a sophisticated artisanship, coupled with the skillful-inverted zoomorphic and anthropomorphic artistic representations (which could allude to the powerful effects of psychedelic fungi on perception, emotion, cognition, and sense of self) [Figure 12; It is noteworthy that the Bribri awápa (indigenous shaman/healers) symbolize the body in inverted form because according to their mythology that is the way in which the spirits see reality. An inverted body image implies that the head is in the feet since it is the former that is rooted to the ground. Consequently, the healing ritual is done from the bottom up, in order to "start from the head" (Bozzoli, 1988).], compels us to consider as reasonable the assertion that these artifacts were associated in some way with the ritualized consumption of psychoactive fungi. Moreover,

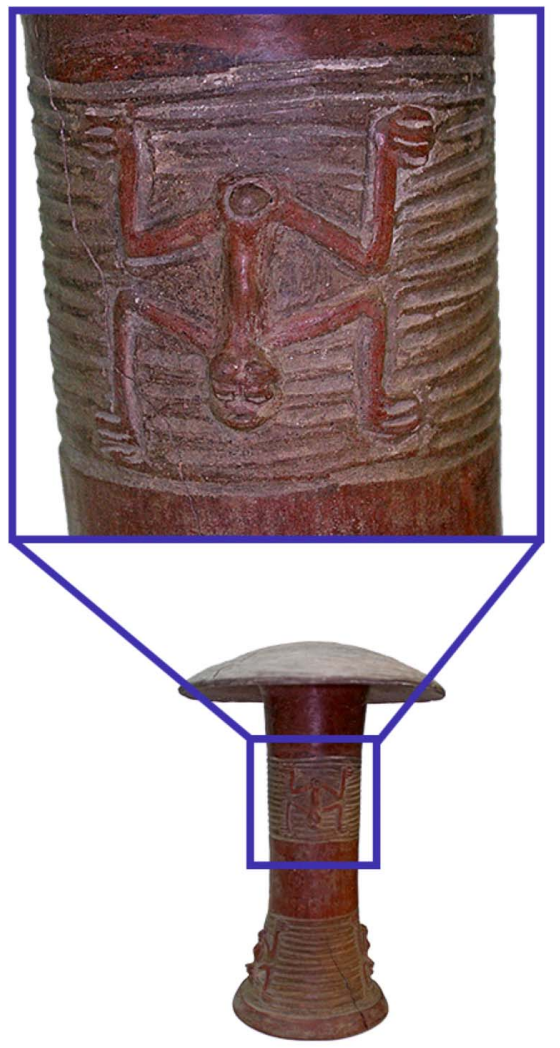

(a)

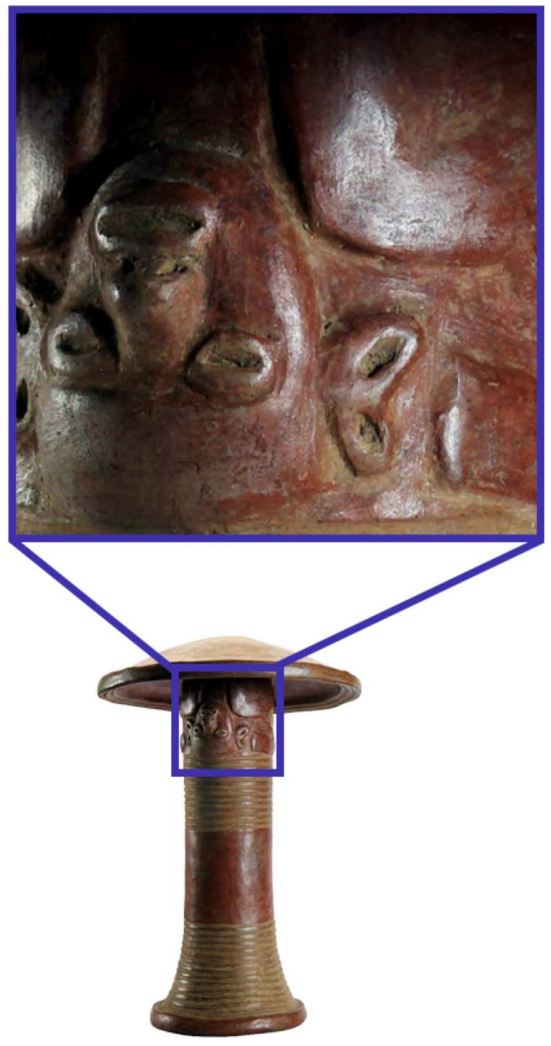

(b)

Figure 12. Detail of the inverted zoomorphic and anthropomorphic artistic motifs on two of the mushroom-shaped ceramic vessels from the Greater Nicoya region. It is possible that the tridimensional upturned personages symbolize the mind-body state change elicited by the ingestion of psychedelic mushrooms. (a) Mushroom-shaped sculpture, National Museum of Costa Rica, no. 1458; (b) mushroom-shaped sculpture, Museum of Jade and Pre-Columbian culture (after Gómez, n.d., pp. 34-35) 
the placement of one of the three mushroom ceramic vessels in a funerary context (Stone, 1977) reinforces this interpretation (for the other two mushroom artifacts the context in which they were found are unknown). Of course, specific ways in which this hypothesis can be further tested and verified must yet be determined and pursued.

Finally, regarding the finding of charred morning glory seeds in storage pits at the Barreal de Heredia site, it must be mentioned that this archeobotanical finding does not necessarily mean the seeds were consumed for their psychoactive properties. As Guerra-Doce (2014) stresses, plant remains recovered from archeological contexts could have had a number of other uses; similarly, they might have grown as weeds among the crops and been harvested unintentionally, or they might have been used as animal fodder, among other possibilities. In Mexico, the Mazatecs process the morning glory seeds by grinding them to a powder, which is then consumed in a cold water infusion (Schultes et al., 2001). Therefore, future archeological starch grain analysis of milling bases (i.e., metates) from the Barreal de Heredia site (and other sites nearby) may help us confirm if these seeds were actually processed and possibly consumed as drugs.

\section{What was the cultural significance of the consumption of psychoactive plants and mushrooms in ancestral Costa Rica?}

In Costa Rica, most of the evidence for the use of psychoactive plants and fungi in prehistoric times (a small and fragmentary data set) are found in sites linked to ritual activity, in this case, tombs. Guerra-Doce (2014, 2015) argues there is a recurrent worldwide association of psychoactive substances with funerary and ceremonial contexts, and she interprets this connection as evidence that inebriants were reserved for specific events, in which they were consumed in order to modify the usual state of consciousness or even to enter ecstatic states (Guerra-Doce, 2014). According to Dietler and Hayden (2001), important events require the consumption of special items that are the most expensive, the rarest, or the most labor intensive to produce. Fernandez de Oviedo's (1851) ethnographic account of the communal celebrations connected to the reception of the cacique Nambí, in the 16th century Nicoya, describes how the ingestion of large quantities of mood- and mind-altering drinks and substances (maize beer, cacao brew, and tobacco cigars) had a prominent role on this particular occasion. Taking into account the effort put into the cultivation of these plants as well as the ritualized way in which they were prepared, presented, and consumed, it seems they were highly valued items that were imbued with a considerable symbolic worth. At least during the initial contact period, tobacco (as wells as cacao and maize beverages) can be linked to important social-ceremonial events [It is unclear whether tobacco was also consumed during traditional mortuary rites; however, Pittier (1938) discusses the "dance of the bones," a funerary celebration that could extend for several days. It was a ceremony that used to take place a year later after the death of a person, and in which the bones of the deceased, already cleaned, were wrapped and buried definitely in the cemetery corresponding to his or her origin clan. It seems the rites consisted of a great spree, in which dancing would not end until they had eaten the last animal the deceased had left (Boza, 2018); thus, the ceremony entailed feasting and the consumption of significant quantities of chicha at the burial place (Stone, 1961).].

There is also evidence that tobacco was considered a medicinal remedy, and that it played a vital role in the belief systems of the Bribri and Cabecar people. The smoking of tobacco is reported by chroniclers and anthropologists (Bozzoli, 1992; Gabb, 1875; Lines, 1945) to have been used for magico-religious practices since the beginnings of the colonial period, and it continued to be fundamental in aboriginal traditional medicine and spiritual activities until well into the twentieth century. For instance, Gabb (1875) and Pittier (1938) describe how, as a central part of the curing sessions and childbirth instances, the awá lighted a pipe with tobacco, smoked from it, and blew whiffs of smoke at the patient or the mother giving birth, respectively. A similar practice of puffing tobacco smoke is described as a means to affect the weather or influence luck.

Concomitantly, it seems tobacco was linked to the practices of the great ritual specialists in charge of controlling powerful magic and mediating the relations with the sacred and supernatural aspects of nature and the cosmos. This association of tobacco with the ritualistic and ceremonial activities of the foremost politico-religious chiefs finds support in the ethnographic and mythological references to the employment of tobacco by the usekölpa specifically to contact and appease powerful supernatural beings that threatened the joint destiny of the Bribri and Cabecar communities (Bozzoli, 1992; Fernández, 2011). According to Bozzoli (1992), the usêkölpa also used tobacco smoke to wage war against the Teribes; by fumigating the enemy warriors with it they supposedly made them fall asleep making it easier to defeat them.

It must be noted that the usêkölpa lived apart from the rest of the group, were considered to have great magicoreligious power (which generated respect and fear), and dealt exclusively with phenomena that affected the communities in a collective way, such as plagues, droughts, epidemics, and wars (Boza, 2018; Bozzoli, 1992; Guevara, 2009). They were thus regional leaders that directed the supra-local community, kept it safe from misfortunes, and oriented it spiritually and martially. These ritual specialists received a long training that provided them with an extensive knowledge about nature, history, religious rituals, magic, sorcery, and medicine (Borge \& Villalobos, 1994). When a sickness or imbalance was community-wide, affecting an entire village, town, or even a whole landscape, the usêkölpa and their abilities came to the forefront. In other words, they were called into action when macro-illnesses (Hoopes, 2013) needed to be addressed and removed to ensure the health of a whole community. In addition, the usêkölpa were believed to be able to transform into fearsome jaguars (Guevara, 2009) and to perform maleficent magic, witchcraft, or sorcery (i.e., to cause macro-illnesses; Boza, 2018; Bozzoli, 1992), a strategy used against enemies as a form of metaphysical warfare (Hoopes, 2013). Importantly, this ability to address and inflict macro-illnesses was one of the main sources of high-ranking authority in ancient Central America in general (Hoopes, 2013). 
Taking into account the remarkable stability and cultural continuity of social life (as seen also in genetic and linguistic data) in prehistoric southern Central American groups (Geurds, 2018), it seems reasonable to assume that, in the distant past, tobacco was also used for the diverse instrumental and fraternal purposes described (and many others, possibly). Tobacco was likely employed entheogenically in prehistory, and it may have come to occupy mainly the function of a social stimulant and "helper" for healing in more recent times. Thus, as is the case for many preindustrial societies around the world (Goodman, Sherratt, \& Lovejoy, 2007; Guerra-Doce, 2015), psychoactive drug use in ancestral Costa Rica probably covered a spectrum of practices (religious, medical, and secular), was to some extent a socially regulated activity due to the potential of these substances to accrue symbolic meanings, and was considered a powerful way of access to esoteric knowledge and communication with other worlds (e.g., of the ancestors and supernatural entities).

The information regarding tobacco consumption, although somewhat limited, allows for a partial reconstruction of the prehistoric patterns of its use. An important pending question is whether tobacco alone was consumed or if it was mixed with other psychoactive herbs as was the case for most of the smoking practices in the rest of the Americas (Carmody et al., 2017; Pennacchio, Jefferson, \& Havens, 2010). On the other hand, the scarce archeological evidence for the use of cohoba, psychedelic mushrooms and morning glory seeds, coupled with the complete absence of descriptions of their ingestion in the scant historic and ethnographic documents, makes it difficult to further explore the social uses of these substances. One might be tempted to conclude they were used very similarly to tobacco (if they were used at all!), but, to be supported, such a claim would require further excavations in primary contexts as well as paleobotanical and chemical analyses of the objects recovered. Some of the artifacts in the museums' collections investigated here, particularly pipes and inhalers, also warrant further examinations of this kind. The same can be stated about certain large pottery jars presumably used for fermenting and storing chicha (Stone, 1961), which might hold important clues about the nature of the alcoholic beverages consumed. Other artifacts (not examined here, but included in the research program) such as incense burners and trays used for holding cacao jars will also be helpful in further clarifying the issue of psychoactive drug use in Costa Rican antiquity.

\section{CONCLUSIONS}

It is possible that mind-altering substances played a role in the healing and divination activities of shamanistic healers in both tribal and chiefdom societies. It seems the psychostimulant tobacco was particularly important in this context. Regarding the impact of psychoactive fungi and plants on cultural dynamics, it is hypothesized that it was more pronounced in emerging complex tribal and chiefly ranked communities. The increasing visibility of the material culture linked to psychoactive drug use during the period between $300 \mathrm{BCE}$ and $300 \mathrm{CE}$ (in some cases extending to ca. $750 \mathrm{CE}$; Figure 10), a time of incipient sociopolitical complexification previous to the establishment of chiefdoms (Arias \& Murillo, 2014; Geurds, 2018) may be evidence of this augmented relevance. Moreover, as mentioned earlier, during this period, ritual activity became exceptionally important (Fernández, 2013), which highlights the adaptive significance of this type of behavior for these human groups during this particular moment in time.

It must be remarked that the following periods (from ca. 300 to $1500 \mathrm{CE}$ ) witnessed the development of sociopolitical formations and a further diversification in material culture (Geurds, 2018). During this time, psychoactive drug use seems to have been less relevant in comparison to the previous period, or at least that is what the dwindling presence of some of its material correlates in the archeological record suggests. This process is consistent with the cross-cultural tendency for trance states to become less relevant for magico-religious practitioners as political integration increases (Winkelman, 1986, 1990). Whitehouse (2004) also documented this growing importance of lowarousal, high-frequency rituals (the "doctrinal" mode), and the relative deemphasis of high-arousal, low-frequency rituals (the "imagistic" mode) with the expansion of societal complexity.

In regard to the increased relevance of psychoactive drug use during the moment in which sociopolitical formations are emerging, this is probably explained by its pragmaticecological value, but also by its role as a specific technique for addressing spiritual issues. It must not be forgotten, as Ripinsky-Naxon (1993) argues, that shamanism is both a psychocultural adaptive mechanism and a mythico-religious idiom. Thus, it is possible that in the context of a shamanistic cosmology and praxis, the ritual consumption of psychoactive fungi and plants favored corrective feedback processes in relation to the culture-environment system (e.g., granting the ritual leaders an expanded capacity to visualize higher-order social and natural dysfunctions and imbalance, enabling them to recognize and address macroillnesses); while, concomitantly, it nurtured the basic human need for meaning.

It is clear that the communities that roamed, changed, and settled in the diverse landscapes of ancient Costa Rica were not isolated from the rest of the region's human groups (Arias \& Murillo, 2014; Geurds, 2018). In prehistoric Central America, towns and villages were connected by ties of kinship, shifting alliances, material exchanges, and participation in common practices mediating relations with the sacred and the supernatural through divination, ritual, and ceremony (Joyce, 2013a). According to Hoopes (2013), throughout the region, there is evidence that social and religious or spiritual authorities were intimately linked. Thus, in these societies, civil actions were not isolated; instead, they were accompanied by an important counterpart of a religious nature (Ibarra, 1999). For instance, it is known that the Talamancan useköl, basically a priest according to Winkelman's (1992) cross-cultural study of magicoreligious practitioners, advised the civil officials about how to act in adverse situations, including war (Ibarra, 1999). He not only propitiated and supplicated supernatural beings, and acted as moral leader, but also administered justice (Aguilar, 1986) and controlled the access to certain goods as 
well as their distribution in certain areas (Ibarra, 1999). Therefore, it becomes difficult to understand expressions of power without taking into account both the spiritual and political aspects of its exercise. The shaman-priests (to borrow VanPool's, 2009 characterization of ritual specialists with mixed traits) of ancestral Costa Rica were magico-religious practitioners that likely possessed significant sociopolitical authority and communal leadership functions too.

Special objects were used by certain individuals to assert their authority. The products of skilled artisans (including the pipes, inhalers, vessels, and pendants examined here), with imagery reflecting religious and spiritual concepts, were used by people who established and exercised their authority through the actions they performed with these objects (Hoopes, 2013). Moreover, the products of skillful artisans located at a distance metaphorically stood for claims of knowledge from the most distant realms - those of the ancestors and supernatural beings (Helms, 1998; Quilter \& Hoopes, 2003). In consequence, according to Ibarra (1999), the possession of such sacred objects among the elite suggests a conception of power associated with knowledge or wisdom, to the management of magico-religious forces, and to the propitiation and establishment of relationships with supernatural beings for the common good and for protection against enemies.

In this particular ideological and material milieu, and especially during the times when political power was in the process of formation (ca. $300 \mathrm{BCE}-750 \mathrm{CE}$ ), the effects of psychedelics and perhaps other mind-altering materials (e.g., chicha and cacao) might have been attractive for some individuals, seeing as these substances can act as vehicles that bind persons, groups, and cultures together across time and space (Winter, 2000), and are often conceived as powerful tools of access to esoteric knowledge and communication with other worlds (Goodman et al., 2007; Guerra-Doce, 2015; Schultes et al., 2001). If this was the case in ancestral Costa Rica, possessing certain control over the ceremonies and ritual knowledge associated with the production and/or use of (certain) inebriants could have become an effective strategy of influence, prestige, and assertion of authority. This process of parlaying access to and knowledge of psychoactive materials and their utilization into differential authority and power is hypothesized to have played a role in the evolution of more complex religious organization. This, in turn, could have influenced the community structures related to decision-making and the coordination of tasks that emerged to manage the growing social complexity of an expanding political system.

The ritual consumption of psychoactive fungi and plants may have provided an ideological means to construct and uphold political power. In historically and ethnographically known chiefdoms, chiefs generally maintain political power through varying strategies for accumulating and disbursing material resources, but also through ideological means (e.g., manipulating cosmologies, ritual, and myth) and military coercion (Earle, 1997; Junker, 2015). Moreover, it has been recognized that as societies become more complex, psychedelics tend to be removed from widespread consumption, their use often becoming restricted to an exclusive practice of a priestly class (Guerra-Doce, 2006;
Winkelman, 1991). Thus, it is possible that in prehistoric Costa Rica, power-seeking individuals assumed the prerogative over the consumption of psychedelic mushrooms and nasally insufflated tobacco and/or cohoba, instrumentalizing and monopolizing these ritual activities to legitimize their role as magico-religious specialists and sociopolitical leaders. Such differentiated use likely reinforced their exclusivity and enhanced their prestige.

Possible evidence for this cultural process can be found in the placement of one of the mushroom-shaped ceramic statues in an elite burial along with sumptuary symbolic objects (carved jade effigies); also, in the fact that only inhalers seem to have been employed as insignia of political and ceremonial rank, as is suggested by the presence of worn down orifices for suspending them as pendants. Moreover, the standardization of the production techniques associated with the elaboration of the mushroom vessels, metates, and gold pendants, as well as the inhalers, attests to the growing social relevance of the activities performed by the magico-religious practitioners that employed these objects. Finally, this line of reasoning predicts that in sites from relatively later periods nasal inhalers (and not pipes) should be found in elite (or higher relative status) burials.

No clear conclusions can be easily advanced on this complex and understudied subject matter. The ethnographic and ethnohistorical references, as well as the ancient material culture, indicate that the consumption of mood- and mind-altering fungi and plants was present among the tribal and chiefdom societies that formerly inhabited the territory that is now Costa Rica. In general, tobacco, cacao, as well as maize, and pejibaye chicha were probably the main psychoactive materials utilized. There are also some hints of the ingestion of morning glory and cohoba seeds, as well as psilocybin and fly agaric mushrooms that precise further substantiation.

It is uncertain how relevant psychoactive drug use was to prehistoric healing and divination practices, although tobacco utilization was clearly associated with the awápa or shaman/healers during the contact period and afterward. The consumption of cacao and chicha has probably been a central element of certain social-ceremonial activities, such as feasts, funerary rites, and some public celebrations since rather ancient times. Finally, it is possible that the use of certain inebriants (particularly psychedelics) was socially differentiated to some degree (especially in emerging chiefly ranked communities), and that it represented a source of insight and specialized knowledge that supported the ritual practices of people who held positions of religious and political importance within society.

Acknowledgements: The authors would like to thank Director Lic. Virginia Vargas and Curator Lic. Priscila Molina from the Museums Foundation of the Central Bank of Costa Rica for the opportunity to work with the collection of artifacts guarded by this institution; Lic. Marlín Calvo and Cleria Ruiz, MSc from the Department of Heritage Protection of the National Museum of Costa Rica for providing access to their collection of archeological artifacts; Michael Winkelman, $\mathrm{PhD}$ and two anonymous reviewers for valuable observations and criticisms on the paper; Mr. Daniel 
Rodríguez, for the processing of most of the images of the artifacts; Lic. Milagro Mata and Barry E. Hammel, PhD from the National Biodiversity Institue (INBio), as well as Agustín Contreras, MSc from the Ark Herb Farm for providing helpful information regarding the biogeographical range of some of the plants and fungi investigated; and Jeffrey Peytrequín, PhD, Mónica Aguilar, MSc, Lic. Natalia Villalobos, and Ricardo Vázquez, PhD for their support and feedback. All photographs of artifacts were taken by MAAC, unless otherwise indicated. The authors state that this work is self-supported.

Conflict of interest: The authors declare no conflict of interest.

\section{REFERENCES}

Aguilar, C. H. (1986). Religión y magia entre los indios de Costa Rica de origen sureño: chamanismo [Religion and magic among the Costa Rican Indians of southern origin: Shamanism]. San José, Costa Rica: Editorial de la Universidad de Costa Rica.

Arce, M. A., \& Rodríguez, J. M. (2018, March 20). Consumo de plantas y hongos psicoactivos en las culturas precolombinas de Costa Rica [Consumption of psychoactive plants and fungi in the pre-Columbian cultures of Costa Rica]. Drogas, Política y Cultura. Retrieved from https://drogaspoliticacultura.net/psa/ consumo-de-plantas-y-hongos-psicoactivos-en-las-culturasprecolombinas-de-costa-rica/

Arias, A. C., \& Murillo, M. (2014). Las sociedades ancestrales del Valle Central de la actual Costa Rica (1000 a.C.-1550 d.C.) [The ancestral societies of the Central Valley of present-day Costa Rica (1000 a.C.-1550 d.C.)]. Revista de Historia, 70, 197-226. Retrieved from https://www.academia.edu/13186083/Las_ sociedades_ancestrales_del_Valle_Central_de_la_actual_Costa_ Rica_1000_a.C.-1550_d.C._

Arford, M., \& Horn, S. (2004). Pollen evidence of the earliest maize agriculture in Costa Rica. Journal of Latin American Geography, 3(1), 108-115. doi:10.1353/lag.2005.0001

Benítez, F. (2006). Los indios de México [The Indians of Mexico]. Mexico City, Mexico: Era Publications.

Bennett, B. C. (1992). Hallucinogenic plants of the Shuar and related indigenous groups in Amazonian Ecuador and Peru. Brittonia, 44(4), 483-493. doi:10.2307/2807199

Blanco, A. M., \& Mora, G. (1995). Plantas silvestres y cultivadas según la evidencia arqueobotánica en Costa Rica [Wild and cultivated plants according to archaeobotanical evidence in Costa Rica (1000 a.C.-1550 d.C.)]. Vinculos, 20(1-2), 53-77. Retrieved from http://biblioteca.museocostarica.go.cr/articulo. aspx?id=3457\&art $=17784$

Blanco, A. M., \& Salgado, S. (1980). Rescate arqueológico del sitio 26-CN Barreal de Heredia [Archaeological rescue of the site 26CN Barreal de Heredia]. In National Organizing Commission (Ed.), V centenario de Gonzalo Fernández de Oviedo: Memoria del Congreso sobre el mundo centroamericano de su tiempo [V centenary of Gonzalo Fernández de Oviedo: Report of the Congress on the Central American world of his time] (pp. 133-138). San José, Costa Rica: Editorial Texto Ltd.
Borge, C., \& Villalobos, V. (1994). Talamanca en la encrucijada [Talamanca at the crossroads]. San José, Costa Rica: EUNED.

Boza, A. (2018). Economía, Estado y comunidades indígenas en Talamanca, Costa Rica. 1927-1948 [Economy, state and indigenous communities in Talamanca, Costa Rica. 19271948]. Cuadernos Intercambio sobre Centroamérica y el Caribe, 15(1), 100-132. doi:10.15517/c.a..v15i1.32947

Bozzoli, M. E. (1988). La conceptualización del cuerpo humano en el chamanismo talamanqueño [The conceptualization of the human body in Talamanca's shamanism]. Bogotá, Colombia: No. 5 Congreso Internacional de Americanistas.

Bozzoli, M. E. (1992). Especialistas en la medicina aborigen Bribri [Specialists in Bribri aboriginal medicine] (Unpublished preliminary report). San José, Costa Rica: School of Anthropology, University of Costa Rica.

Cardeña, E., \& Winkelman, M. (Eds.). (2011). Altering consciousness: Multidisciplinary perspectives. Santa Barbara, CA: Praeger.

Carmody, S. B., Caffrey, M. A., Lady, B. S., \& Horn, S. P. (2017). Palynological and chemical analyses of prehistoric pipe residues as evidence of tobacco use in Tennessee. Tennessee Archaeology, 9(1), 5-15. Retrieved from https://www. researchgate.net/publication/312166456_Palynological_and_ chemical_analyses_of_prehistoric_pipe_residues_as_evidence_ of_tobacco_use_in_Tennessee

de Borhegyi, S. F. (1961). Miniature mushroom stones from Guatemala. American Antiquity, 26(04), 498-504. doi:10.2307/ 278737

de Borhegyi, S. F. (1963). Precolumbian pottery mushrooms from Mesoamerica. American Antiquity, 28(3), 328-338. doi:10. 2307/278276

Dietler, M., \& Hayden, B. (Eds.). (2001). Feasts: Archaeological and ethnographic perspectives on food, politics, and power. Washington, DC: Smithsonian Institution Press.

Dobkin de Ríos, M. (1984). Hallucinogens: Cross-cultural perspectives. Albuquerque, NM: University of New Mexico Press.

Drennan, R. D. (1995). Chiefdoms in Northern South America. Journal of World Prehistory, 9(3), 301-340. doi:10.1007/ BF02221116

Earle, T. (1997). How chiefs come to power: The political economy in prehistory. Redwood City, CA: Stanford University Press.

Emmerich, A. (1965). Sweat of the sun and tears of the moon; Gold and silver in pre-Columbian art. Seattle, WA: University of Washington Press.

Falchetti, A. M. (1979). Colgantes 'Darién.' Relaciones entre áreas orfebres del occidente Colombiano y Centroamérica ['Darién' pendants. Relationship between the gold working traditions of Western Colombia and Central America]. Boletín, 2, 1-55. Retrieved from https://publicaciones.banrepcultural.org/index. $\mathrm{php} / \mathrm{bmo} /$ article/view/7351/7620

Fallas, M. A. (1972). La factoría de tabacos de Costa Rica [The Costa Rican tobacco factory]. San José, Costa Rica: Editorial Universidad de Costa Rica.

Fernández, P. (2004). Sellos precolombinos: Imágenes estampadas de Costa Rica [Pre-Columbian stamps: Printed images of Costa Rica]. San José, Costa Rica: Master Litho.

Fernández, P. (2013). Between beliefs and rituals: Material cultures of ancestral Costa Rica. In R. A. Joyce (Ed.), Revealing ancestral Central America (pp. 59-67). Washington, DC: Smithsonian Latino Center and the National Museum of the 
American Indian, Smithsonian Institution. Retrieved from https://escholarship.org/uc/item/9786j9b5

Fernández, S. (2011). Recopilación de historias "El banquete de Sibö" [Compilation of stories "The banquet of Sibö"]. San José, Costa Rica: Editorial Fundación Nairi.

Fernández de Oviedo y Valdés, G. (1851). La historia general y natural de las Indias, parte III (originally written in 1535) [The general and natural history of the Indies, part III (originally written in 1535)]. Madrid, Spain: Real Academia de la Historia.

Ferreira, W. S., Jr., Cruz, M. P., Vieira, F. J., \& de Albuquerque, U. P. (2010). Are hallucinogenic plants efficacious in curing diseases? Boletín Latinoamericano y del Caribe de Plantas Medicinales y Aromáticas, 9(4), 292-301. Retrieved from http://www.redalyc.org/html/856/85615195007/index.html

Ferrero, L. (1977). Costa Rica preColombina. San José, Costa Rica: Editorial Costa Rica.

Field, L. (2012). El sistema del oro: Exploraciones sobre el destino (emergente) de los objetos de oro precolombinos en Colombia [The gold system: Explorations on the (emerging) fate of preColumbian gold objects in Colombia]. Antipoda: Revista de Antropología y Arqueología, 14(14), 67-94. doi:10.7440/ antipoda14.2012.04

Fonseca, O. (2003). Historia antigua de Costa Rica: Surgimiento y caracterización de la primera civilización costarricense [Ancient history of Costa Rica: Emergence and characterization of the first Costa Rican civilization]. San José, Costa Rica: Editorial de la universidad de Costa Rica.

Forbey, J. S., Harvey, A. L., Huffman, M. A., Provenza, F. D., Sullivan, R., \& Tasdemir, D. (2009). Exploitation of secondary metabolites by animals: A response to homeostatic challenges. Integrative and Comparative Biology, 49(3), 314-328. doi:10. 1093/icb/icp046

Fortis, P. (2015). Smoking tobacco and swinging the chicha: On different modes of sociality among Guna ('Kuna') people. In A. Russell \& E. Rahman (Eds.), The master plant: Tobacco in Lowland South America (pp. 199-214). London, UK: Bloomsbury Academic. Retrieved from http://dro.dur.ac.uk/16894/

Furst, P. T. (Ed.). (1990). Flesh of the Gods: The ritual use of hallucinogens. Long Grove, IL: Waveland Press.

Gabb, W. M. (1875). On the Indian tribes and languages of Costa Rica. Proceedings of the American Philosophical Society, 14, 483-602. Retrieved from https://archive.org/ details/onindiantribesla00gabb/page/n7

Geurds, A. (2018). Prehistory of Southern Central America. In C. Smith (Ed.), Encyclopedia of global archaeology. New York, NY: Springer. Retrieved from https://www.academia.edu/ 37600614/Prehistory_of_Southern_Central_America

Gómez, L. A. (n.d.). El Jade: Museo Del Jade y de la Cultura Precolombina. Nivel 02: autoguía [Jade: Museum of Jade and pre-Columbian culture. Level 02: Self-guide]. Retrieved February 25, 2019, from http://www.museodeljadeins.com/ Recursos/PDF/Autoguia_Jade_.pdf

Goodman, J., Sherratt, A., \& Lovejoy, P. E. (Eds.). (2007). Consuming habits: Drugs in history and anthropology. New York, NY: Routledge.

Guerra-Doce, E. (2006). Las drogas en la prehistoria: Evidencias arqueológicas del consumo de sustancias psicoactivas en Europa [Drugs in prehistory: Archaeological evidence of the consumption of psychoactive substances in Europe]. Barcelona, Spain: Bellaterra.
Guerra-Doce, E. (2014). The origins of inebriation: Archaeological evidence of the consumption of fermented beverages and drugs in prehistoric Eurasia. Journal of Archaeological Method and Theory, 22(3), 751-782. doi:10.1007/s10816014-9205-z

Guerra-Doce, E. (2015). Psychoactive substances in prehistoric times: Examining the archaeological evidence. Time \& Mind, 8(1), 91-112. doi:10.1080/1751696X.2014.993244

Guerrero, M. (Ed.). (2012). Taínos. Santo Domingo, República Dominicana: Odebrecht.

Guevara, M. (2009). Sobre el valor pragmático del mito. Apuntes desde la mitología comparada de Talamancas y Kunas [On the pragmatic value of myth. Notes from the comparative mythology of Talamancans and Kunas]. Anuario de Estudios Centroamericanos, 35-36, 11-35. Retrieved from https://www. jstor.org/stable/41306411?seq=1\#page_scan_tab_contents

Guzmán, G. (2013). Sacred mushrooms and man: Diversity and traditions in the world, with special reference to Psilocybe. In J. A. Rush (Ed.), Entheogens and the development of culture: The anthropology and neurobiology of ecstatic experience (pp. 485-518). Berkeley, CA: North Atlantic Books.

Hammel, B. E. (2005). Plantas ornamentales nativas de Costa Rica [Native ornamental plants of Costa Rica] (3rd ed.). Santo Domingo, Heredia: Editorial INBio.

Hammel, B. E., Grayum, M. H., Herrera, C., \& Zamora, N. (Eds.). (2015). Manual de plantas de Costa Rica [Manual of plants of Costa Rica] (Vol. VIII). St. Louis, MO: Missouri Botanical Gardens Press.

Harner, M. J. (Ed.). (1973). Hallucinogens and shamanism. Oxford, UK: Oxford University Press.

Helmreich, I. (1975). Coca pouches from Colombia. Indiana, 3, 111-126. doi:10.18441/ind.v3i0.111-126

Helms, M. (1998). Access to origins: Affines, ancestors, and aristocrats. Austin, TX: University of Texas Press.

Hoopes, J. W. (2013). Authority. In R. A. Joyce (Ed.), Revealing ancestral Central America (pp. 45-58). Washington, DC: Smithsonian Latino Center and the National Museum of the American Indian, Smithsonian Institution. Retrieved from https://escholarship.org/uc/item/9786j9b5

Ibarra, E. (1999). Política y etnicidad en sociedades en transición en la zona sur de Costa Rica: Boruca y Talamanca siglos XVI al XIX [Politics and ethnicity in transition societies in the southern zone of Costa Rica: Boruca and Talamanca from the 16th to 19th centuries]. Vinculos, 24(1-2), 121-151. Retrieved from https://ehrafworldcultures.yale.edu/document? id=sa19-009

Jara, V., \& García, A. (Eds.). (2003). Diccionario de mitología Bribri [Dictionary of Bribri mythology]. San José, Costa Rica: Editorial Universidad de Costa Rica.

Jones, U. (1991). Metates and hallucinogens in Costa Rica. Papers from the Institute of Archaeology, 2, 29-34. doi:10.5334/pia.18

Joyce, R. A. (2013a). Surrounded by beauty: Central America before 1500. In R. A. Joyce (Ed.), Revealing ancestral Central America (pp. 13-21). Washington, DC: Smithsonian Latino Center and the National Museum of the American Indian, Smithsonian Institution. Retrieved from https://escholarship. org/uc/item/9786j9b5

Joyce, R. A. (Ed.). (2013b). Revealing ancestral Central America. Washington, DC: Smithsonian Latino Center and the National Museum of the American Indian, Smithsonian Institution. Retrieved from https://escholarship.org/uc/item/9786j9b5 
Junker, L. L. (2015). Chiefdoms, archaeology of. In J. Wright (Ed.), International encyclopedia of the social and behavioral sciences (2nd ed.). Amsterdam, The Netherlands: Elsevier.

Kennedy, D. O. (2014). Plants and the human brain. New York, NY: Oxford University Press.

Köhler, U. (1976). Mushrooms, drugs, and potters: A new approach to the function of pre-Columbian Mesoamerican mushroom stones. American Antiquity, 41(2), 145-153. doi:10. 2307/279165

Leigh, E., O’Dea, A., \& Vermeij, G. (2013). Historical biogeography of the Isthmus of Panama. Biological Reviews, 89(1), 148-172. doi: $10.1111 /$ brv. 12048

Lines, J. A. (1945). Notas etnológicas: Sukia, isúgür o isogro [Ethnological notes: Sukia, isúgür or isogro]. Revista de los Archivos Nacionales, 10(1-2), 17-43.

Lines, J. A. (1954). Taxonomía de la arqueología de Costa Rica [Taxonomy of the archeology of Costa Rica]. San José, Costa Rica: Librería Universitaria.

Lothrop, S. K. (1926). The pottery of Costa Rica and Nicaragua, 2 vols. New York, NY: Hege Foundation.

Lowy, B. (1982). Were mushrooms stones potters' molds. Revista/ Review Interamericana, 11(2), 231-237.

Mata, M. (2003). Macrohongos de Costa Rica [Macrofungi of Costa Rica] (2nd ed.). Santo Domingo, Heredia: Editorial INBio.

Müller, C. P., \& Schumann, G. (2011). Drugs as instruments: A new framework for non-addictive psychoactive drug use. Behavioral and Brain Sciences, 34(06), 293-310. doi:10. 1017/S0140525X11000057

Murillo, M., \& Martín, A. J. (2017). La relación entre estructura comunitaria y economía doméstica en cacicazgos del centro y sur de América [The relation between community structure and domestic economy in chiefdoms from Central and South America]. Boletín de Antropología, 32(54), 101-125. doi:10. 17533/udea.boan.v32n54a06

Pennacchio, M., Jefferson, L. V., \& Havens, K. (2010). Uses and abuses of plant-derived smoke: Its ethnobotany as hallucinogen, perfume, incense, and medicine. Oxford, UK: Oxford University Press.

Pérez de Barradas, J. (1954). Orfebrería prehispánica de Colombia: Estilos Calima y Muisca [Prehispanic goldwork of Colombia: Calima and Muisca styles] (Vol. 2). Bogotá, Colombia: Banco de la República.

Peytrequín, J. (2012). Un acercamiento a la historia antigua y cotidianidad del valle central costarricense. 1700 años atrás [An approach to the ancient history and daily life of the central Costa Rican valley. 1700 years ago]. Anuario de Estudios Centroamericanos, 38, 241-278. Retrieved from http://www. jstor.org/stable/43871199

Pittier, H. (1938). Apuntaciones etnológicas sobre los indios bribri [Ethnological insights about the Bribri Indians]. San José, Costa Rica: Museo Nacional.

Quilter, J., \& Hoopes, J. W. (Eds.). (2003). Gold and power in ancient Costa Rica, Panama, and Colombia. Washington, DC: Dumbarton Oaks.

Quirce, C. M., Badilla, B., Badilla, S., Martínez, M., \& Rodríguez, J. M. (2010). Los alucinógenos: Su historia, antropología, química y farmacología [The hallucinogens: Their history, anthropology, chemistry, and pharmacology]. Psicogente, 13(23), 174-192. Retrieved from http://oaji.net/articles/2015/ 1787-1438300645.pdf
Rätsch, C. (2005). The encyclopedia of psychoactive plants: Ethnopharmacology and its applications. Rochester, VT: Park Street Press.

Reichel-Dolmatoff, G. (1953). Contactos y cambios culturales en la Sierra Nevada de Santa Marta [Contacts and cultural changes in the Sierra Nevada of Santa Marta]. Bogotá, Colombia: Instituto Colombiano de Antropología.

Ripinsky-Naxon, M. (1993). The nature of shamanism: Substance and function of a religious metaphor. Albany, NY: State University of New York Press.

Román, J. C. (2007). La ruta de la cojoba: Una investigación necesaria en los campos de la biogeografía y la arqueoetnobotánica [The route of the cojoba: A necessary research in the fields of biogeography and archaeoethnobotany]. Boletin del Archivo General de la Nación, 32(118), 341-358. Retrieved from https://es.calameo.com/read/0005307755a27b0bb346f

Schultes, R. E., \& Bright, A. (1979). Ancient gold pectorals from Colombia: Mushroom effigies? Botanical Museum Leaflets, 27(5-6), 113-141. Retrieved from https://www.jstor.org/ stable/41762817?seq=1\#page_scan_tab_contents

Schultes, R. E., Hofmann, A., \& Rätsch, C. (2001). Plants of the gods: Their sacred, healing, and hallucinogenic powers. Rochester, VT: Healing Arts Press.

Siegel, R. K. (2005). Intoxication: The universal drive for mindaltering substances. Rochester, VT: Park Street Press.

Skinner, A. (1920). Notes on the Bribri of Costa Rica. Indian notes and monographs. New York, NY: Museum of the American Indian, Heye Foundation. Retrieved from http:// ehrafworldcultures.yale.edu/document?id=sa19-002

Snarskis, M. (1978). The archaeology of the Central Atlantic watershed of Costa Rica (Unpublished doctorate thesis). New York, NY: University of Columbia.

Snarskis, M. (1983). La cerámica precolombina en Costa Rica [Pre-Columbian ceramics in Costa Rica]. San José, Costa Rica: Instituto Nacional de Seguros de Costa Rica.

Snarskis, M. (2009, March 27). Agricultural villages, chiefdoms \& better pottery. The Tico Times. Retrieved from http://www. ticotimes.net/2009/03/27/agricultural-villages-chiefdoms-betterpottery

Stone, D. Z. (1961). Las tribus talamanqueñas de Costa Rica [The Talamancan tribes of Costa Rica]. San José, Costa Rica: Museo Nacional de Costa Rica/Editorial A. Lehmann.

Stone, D. Z. (1966). Introducción a la arqueología de Costa Rica [Introduction to the archeology of Costa Rica]. San José, Costa Rica: Museo Nacional de Costa Rica.

Stone, D. Z. (1977). El hombre preColombino en Costa Rica [The pre-Columbian man in Costa Rica]. Cambridge, MA: Peabody Museum Press.

Stone, R. R. (2011). The jaguar within: Shamanic trance in ancient Central and South American art. Austin, TX: University of Texas Press.

Torres, C. M. (2006). Los colgantes Darién: ¿evidencia para el uso de hongos visionarios en los Andes Septentrionales? [The Darien pendants: Evidence for the use of visionary mushrooms in the Northern Andes?]. Revista Cultura y Droga, 11, 47-62. Retrieved from https://docplayer.es/71561682-Los-colgantesdarien-evidencia-para-el-uso-de-hongos-visionarios-en-losandes-septentrionales-constantino-manuel-torres.html

VanPool, C. S. (2009). The signs of the sacred: Identifying shamans using archaeological evidence. Journal of Anthropological Archaeology, 28(2), 177-190. doi:10.1016/j.jaa.2009.02.003 
Vázquez, R. (2002). Arqueología del área de influencia del Proyecto Hidroeléctrico Angostura. Informe Final de Operaciones [Archeology of the area of influence of the Angostura Hydroelectric Project. Final Operations Report]. San José, Costa Rica: Museo Nacional de Costa Rica/Instituto Costarricense de Electricidad.

Vázquez, R. (2010). Visiones y sensaciones cefalográficas en un petroglifo prehispánico de Colonia Blanca de Upala, Costa Rica [Cephalographic visions and sensations in a pre-Hispanic petroglyph of Colonia Blanca of Upala, Costa Rica]. Vínculos, 22(1-2), 47-62. Retrieved from http://origenes.museocostarica.go.cr/Files/Document/Visiones $\% 20 y \% 20$ sensaciones.pdf

Villalba, J. J., \& Provenza, F. D. (2007). Self-medication and homeostatic behavior in herbivores: Learning about the benefits of nature's pharmacy. Animal, 1(9), 1360-1370. doi:10. 1017/S1751731107000134

Whitehouse, H. (2004). Modes of religiousity: A cognitive theory of religious transmission. Walnut Creek, CA: Altamira Press.

Wilbert, J. (1987). Tobacco and shamanism in South America. New Haven, CT: Yale University Press.

Wink, M., \& van Wyk, B. (2008). Mind-altering and poisonous plants of the world: A scientifically accurate guide to
1200 toxic and intoxicating plants. Portland, OR: Timber Press.

Winkelman, M. (1986). Magico-religious practitioner types and socioeconomic conditions. Cross-Cultural Research, 20, 17-46. doi:10.1177/106939718602000102

Winkelman, M. (1990). Shamans and other "magico-religious" healers: A cross-cultural study of their origins, nature, and social transformations. Ethos, 18(3), 308-352. doi:10.1525/ eth.1990.18.3.02a00040

Winkelman, M. (1991). Physiological, social and functional aspects of drug and non-drug altered states of consciousness. In W. Andritzky (Ed.), Yearbook of cross-cultural medicine and psychotherapy (pp. 183-198). Berlin, Germany: VWBVerlag.

Winkelman, M. (1992). Shamans, priests, and witches: A crosscultural study of magico-religious practitioners. Tempe, AZ: Arizona State University.

Winter, J. C. (2000). From Earth mother to snake woman; the role of tobacco in the evolution of Native American religious organization. In J. C. Winter (Ed.), Tobacco use by Native North Americans: Sacred smoke, silent killer (pp. 265-304). Norman, OK: University of Oklahoma Press. 